OPEN ACCESS

Edited by:

Jose M. Garcia-Mina,

Universidad de Navarra, Spain

Reviewed by:

Lourdes Hernandez-Apaolaza, Universidad Autónoma de Madrid,

Spain

Therese McBeath

Commonwealth Scientific

and Industrial Research Organisation

(CSIRO), Australia

*Correspondence:

Zhaojun Nie

nzj0511@126.com

Specialty section: This article was submitted to

Plant Nutrition,

a section of the journal

Frontiers in Plant Science

Received: 08 June 2018

Accepted: 25 September 2018

Published: 12 October 2018

Citation:

Liu H, Zhao P, Qin S and Nie Z

(2018) Chemical Fractions

and Availability of Zinc in Winter Wheat Soil in Response to Nitrogen and Zinc Combinations. Front. Plant Sci. 9:1489.

doi: 10.3389/fpls.2018.01489

\section{Chemical Fractions and Availability of Zinc in Winter Wheat Soil in Response to Nitrogen and Zinc Combinations}

\author{
Hongen Liu, Peng Zhao, Shiyu Qin and Zhaojun Nie* \\ Resources and Environment College, Henan Agricultural University, Zhengzhou, China
}

Nitrogen $(\mathrm{N})$ is critical for zinc $(\mathrm{Zn})$ accumulation in winter wheat grain via enhancing $\mathrm{Zn}$ absorption into plant roots. This paper explored a possible mechanism for enhanced absorption of $\mathrm{Zn}$ in winter wheat by $\mathrm{N}$ combined with $\mathrm{Zn}$ application based on the Zn bio-availability in soil. A pot experiment with three $\mathrm{N}$ application rates $(0.05,0.2$, and $0.4 \mathrm{~g} \mathrm{~kg}^{-1}$ ), two $\mathrm{Zn}$ application rates ( 0 and $10 \mathrm{mg} \mathrm{kg}^{-1}$ ), without and with plants was conducted. The results showed that high $\mathrm{N}\left(\mathrm{N}_{0.2}\right.$ and $\left.\mathrm{N}_{0.4}\right)$ combined with $\mathrm{Zn}\left(Z \mathrm{n}_{10}\right)$ application significantly increased the yield, yield components and $\mathrm{Zn}$ and $\mathrm{N}$ concentrations in winter wheat shoots and grain. The available $\mathrm{Zn}$ concentration in soil with and without plants was increased by $N_{0.2} Z n_{10}$ and $N_{0.4} Z n_{10}$ treatment at each growth stage. $N_{0.2} Z n_{10}$ and $N_{0.4} Z n_{10}$ treatment significantly decreased the $\mathrm{pH}$ in soil without plants but had different influences on the $\mathrm{pH}$ in soil with plants, which depended on the different $\mathrm{N}$ application rates and growth stages. Meanwhile, $N_{0.2} Z n_{10}$ and $N_{0.4} Z n_{10}$ treatment decreased the exchangeable $Z n$ but increased loose organic-, carbonate- and Fe-Mn oxides-bound Zn concentrations in soil without plants. The exchangeable, loose organic- and carbonate-bound $Z n$ concentrations in soil with plants was increased by $N_{0.2} Z n_{10}$ and $N_{0.4} Z n_{10}$ treatment at different growth stages. Different rates of $\mathrm{N}$ combined with $\mathrm{Zn}$ application influenced the proportion of $\mathrm{Zn}$ in different fractions in soil with and without plants at different growth stages. At $Z \mathrm{n}_{10}$, $\mathrm{N}_{0.4}$ treatment showed higher yield, $\mathrm{N}$ and $\mathrm{Zn}$ concentrations in shoot and grain, and available $\mathrm{Zn}$ concentration in soil, but lower $\mathrm{pH}$ in soil than $\mathrm{N}_{0.2}$ treatment. In addition, soil without plants had higher available $\mathrm{Zn}$ concentrations and lower $\mathrm{pH}$ than did the soil with plants. There were significant differences in $\mathrm{Zn}$ chemical fractions concentrations and proportions between the soils with and without plants at each growth stage. Therefore, combined influence of roots and the combination of $\mathrm{N}$ and $\mathrm{Zn}$ (especially $\mathrm{N}_{0.4} \mathrm{Zn}_{10}$ treatment) improved the bio-availability of $\mathrm{Zn}$ in soil via changing the soil $\mathrm{pH}$ and promoting the transformation and distribution of $\mathrm{Zn}$ in different fractions.

\footnotetext{
Keywords: nitrogen, soil available zinc, soil pH, soil zinc chemical fractions, winter wheat, zinc
} 


\section{INTRODUCTION}

Zinc $(\mathrm{Zn})$ is essential for human body and is involved in physiological and nutritional functions in human growth and development, including humoral and cellular immunity as well as the synthesis of proteins and nucleic acids (Bonaventuraa et al., 2015). Zn deficiency results in a series of problems for humans, especially infants, such as loss of appetite and digestion, growth retardation, and brain and immune system dysfunction (Prasad, 2014). $\mathrm{Zn}$ is also a necessary element in plants, and $\mathrm{Zn}$ deficiency in soil can decrease the yield and quality of crops, consequently threatening human health. $\mathrm{Zn}$ deficiency in the body can be resolved by human intervention, including dietary diversification, nutritional supplements, food intensification and biofortification (Graham et al., 2001). For areas with severe zinc deficiency, such as sub-Saharan Africa and South Asia, food crops in those developing countries are the main source of $\mathrm{Zn}$ in the human body. Thus, biofortification of grain crops with $\mathrm{Zn}$ by breeding and fertilization appears to be cost-effective and promising as an approach for improving Zn concentration in grain, thereby contributing to human health (Graham et al., 2001; Bouis et al., 2011; Velu et al., 2014).

As a source of both calories and protein, wheat is one of important crops in many countries (Cakmak, 2008). However, widespread low $\mathrm{Zn}$ concentrations in wheat lead to insufficient intake of $\mathrm{Zn}$ by populations for whom wheat is the staple food. The $\mathrm{Zn}$ concentrations in wheat grain in the Northern Winter Wheat Region of China range from 11.7 to $49.7 \mathrm{mg}$ $\mathrm{kg}^{-1}$, with a mean value of $26.4 \mathrm{mg} \mathrm{kg}{ }^{-1}$ (Zhang et al., 2007; Cao et al., 2010), which is well below the target value of $40-60 \mathrm{mg} \mathrm{kg}^{-1}$ (Ortiz-Monasterio et al., 2007; Cakmak, 2008). The reason for the low $\mathrm{Zn}$ concentration in crop grain is the low level of $\mathrm{Zn}$ supply in soil (Hotz and Brown, 2004). However, $\mathrm{Zn}$ deficiency in soil is common in China (Liu, 1994). Henan Province is the main area for wheat production in China, and more than $60 \%$ of soil has severe $\mathrm{Zn}$ deficiency, approximately $34 \%$ of the soil is possibly $\mathrm{Zn}$ deficient, and only $6 \%$ of the soil is Zn sufficient (Sun and Cai, 1984).

The $\mathrm{Zn}$ adsorption-desorption reactions between the solution and solid phases control $\mathrm{Zn}$ concentrations in soil solution and the availability of $\mathrm{Zn}$ to plants (Lindsay, 1991; Catlett et al., 2002), which depend on the $\mathrm{pH}$, organic matter, soil minerals, and co-existing ions as well as the distribution into various fractions (Alloway, 2008). The $\mathrm{Zn}$ fractions in soil are often distinguished with regard to chemical binding characteristics, including exchangeable, organic matter-bound, carbonate-bound, Fe-Mn oxides and residual $\mathrm{Zn}$ (Tessier et al., 1979; Jiang et al., 1990). Exchangeable $\mathrm{Zn}$ is the most labile binding form and has the closest correlation with $\mathrm{Zn}$ uptake in plants (Chahal et al., 2005; Li et al., 2007). Organic matterbound $\mathrm{Zn}$ is also available to plants due to the exchangeable sites for $\mathrm{Zn}$ in soil solid matrix provided and cation exchange capacity increased by organic matter (Khoshgoftarmanesh et al., 2018). When $\mathrm{Zn}$ is bound to carbonate or Fe-Me oxides in soil, this binding will reduce the bioavailability of $\mathrm{Zn}$ and will enhance the ability of rice to resist $\mathrm{Zn}$ stress (Shuman and Wang, 1997).

Plants have direct or indirect influences on the nutrients availability in diverse ways, such as the release of root exudates (Clemens et al., 2002; Udom et al., 2004). Root exudates in oat can dissolve the heavy metals bound to carbonate and oxides and can convert them to the exchangeable form, improving the availability of heavy metals (Mench and Fargue, 1994). The amino acids secreted by the roots of ryegrass reduce the $\mathrm{pH}$ value of rhizosphere soil and make the organic $\mathrm{Zn}$ of rhizosphere soil higher than that of non-rhizosphere soil (Xu et al., 2007).

$\mathrm{Zn}$ supply is a direct and effective method to solve the low availability of $\mathrm{Zn}$ in soil (Almendros et al., 2013; Guo et al., 2015). Furthermore, nitrogen (N) application or N combined with $\mathrm{Zn}$ application is beneficial for increasing $\mathrm{Zn}$ concentration, enhancing $\mathrm{Zn}$ translocation to grain in wheat, especially when wheat is cultured in Zn-deficient soil (Kutman et al., 2010; Li et al., 2015). $\mathrm{N}$ combined with $\mathrm{Zn}$ application can enhance $\mathrm{Zn}$ uptake via membrane transport and stimulate root development (Nie et al., 2017). When $\mathrm{Zn}$ has been absorbed, $\mathrm{N}$ in combination with $\mathrm{Zn}$ facilitates translocation of $\mathrm{Zn}$ to grain (Zhao et al., 2016). However, little is known about how $\mathrm{N}$ combined with $\mathrm{Zn}$ application affects the $\mathrm{Zn}$ fractions or their availability in soil to increase the absorption of $\mathrm{Zn}$, especially through the root system of plants.

The aims of this study were: (i) to re-examine the effect of $\mathrm{N}$ combined with $\mathrm{Zn}$ application on $\mathrm{Zn}$ concentration in winter wheat; (ii) to investigate available $\mathrm{Zn}, \mathrm{pH}$, and $\mathrm{Zn}$ chemical fractions in soil influenced by the root system of winter wheat; and (iii) to investigate available $\mathrm{Zn}, \mathrm{pH}$, and $\mathrm{Zn}$ chemical fractions in soil in response to different $\mathrm{N}$ application rates, combined with $\mathrm{Zn}$ during pot trials. The results are expected to provide a possible reason for the $\mathrm{Zn}$ absorption enhanced by $\mathrm{N}$ combined with $\mathrm{Zn}$ application from the change in $\mathrm{Zn}$ availability in soil.

\section{MATERIALS AND METHODS}

\section{Plant Growth Description}

Winter wheat (Triticum aestivum cv. Yunong 202) seeds were sown in ceramic bowls (inner diameter $28 \mathrm{~cm}$ and height $20 \mathrm{~cm}$ ) each filled with $8 \mathrm{~kg}$ of $\mathrm{Zn}$-deficient calcareous soil. The ceramic bowls were undrained to avoid the nutrients loss. The physical and chemical properties of soil were as follows: $\mathrm{pH} 7.34$ (soil: water ratio of 1:2.5), organic matter $11.8 \mathrm{~g} \mathrm{~kg}^{-1}$, alkaline hydrolysis $\mathrm{N} 78.4 \mathrm{mg} \mathrm{kg}{ }^{-1}$, Olsen-P $11.0 \mathrm{mg} \mathrm{kg}{ }^{-1}$,

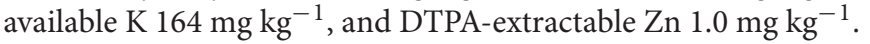
The experiment was conducted at the Science Park of Henan Agricultural University (N $34^{\circ} 52^{\prime}$, E $113^{\circ} 35^{\prime}$ ), Zhengzhou City, Henan Province, China.

\section{Experimental Design}

Two rates of $\mathrm{Zn}\left(0\right.$ and $10 \mathrm{mg} \mathrm{kg}^{-1}$ soil) and three rates of $\mathrm{N}[0.05$ (low), 0.2 (medium), and 0.4 (high) $\mathrm{g} \mathrm{kg}^{-1}$ soil] were applied by using $\mathrm{ZnSO}_{4} \cdot 7 \mathrm{H}_{2} \mathrm{O}$ and $\mathrm{Ca}\left(\mathrm{NO}_{3}\right)_{2} \cdot 2 \mathrm{H}_{2} \mathrm{O}$, respectively. Low $\mathrm{N}$ and medium $\mathrm{N}$ pots were supplemented with $\mathrm{CaCl}_{2} \cdot 2 \mathrm{H}_{2} \mathrm{O}$ 
to ensure the same extra amount of $\mathrm{Ca}$ for all treatments. Six treatments were applied including $\mathrm{N}_{0.05} \mathrm{Zn}_{0}, \mathrm{~N}_{0.2} \mathrm{Zn}_{0}, \mathrm{~N}_{0.4} \mathrm{Zn}_{0}$, $\mathrm{N}_{0.05} \mathrm{Zn}_{10}, \mathrm{~N}_{0.2} \mathrm{Zn}_{10}$, and $\mathrm{N}_{0.4} \mathrm{Zn}_{10}$. Control (no plant) pots were used to compare with the $\mathrm{N}$ and $\mathrm{Zn}$ treatments. Each treatment was replicated three times. To meet the $\mathrm{P}$ and $\mathrm{K}$ requirements, $\mathrm{KH}_{2} \mathrm{PO}_{4}$ and $\mathrm{KCl}$ were applied in each pot at the rates of $0.15 \mathrm{~g}$ $\mathrm{P}_{2} \mathrm{O}_{5} \mathrm{~kg}^{-1}$ soil and $0.20 \mathrm{~g} \mathrm{~K}_{2} \mathrm{O} \mathrm{kg}^{-1}$ soil. Before sowing, all the fertilizers including half of $\mathrm{N}$ for each $\mathrm{N}$ treatment were mixed into a solution with deionized water and supplied into soil, and the remaining $\mathrm{N}$ was split into two equal applications in the soil at the jointing and booting stages. One $\mathrm{mL}$ of Arnon nutrient solution (non-Zn) per kg soil was supplemented to each bowl to avoid trace element deficiency, including Fe-EDTA $0.025 \mathrm{mg}$, $\mathrm{MnCl}_{2} \cdot \mathrm{H}_{2} \mathrm{O} 1.81 \mathrm{mg}, \mathrm{CuSO}_{4} \cdot 5 \mathrm{H}_{2} \mathrm{O} 0.08 \mathrm{mg}, \mathrm{H}_{3} \mathrm{BO}_{3} 2.86 \mathrm{mg}$, and $\left(\mathrm{NH}_{4}\right)_{6} \mathrm{Mo}_{7} \mathrm{O}_{20} 0.02 \mathrm{mg} \mathrm{kg}^{-1}$ soil. All the chemical reagents used were of analytical grade, and deionized water was used during the experimental period.

Twenty seeds were sown in each pot on October 17, 2015, and ten seedlings were retained in each pot after thinning. The shoots of winter wheat and soils with and without plants were sampled at the tillering (85 days, Zadoks stage: 23), jointing (168 days, Zadoks stage: 36), grain filling (192 days, Zadoks stage: 77) and mature (216 days, Zadoks stage: 99) stages, as well as grain at the mature stage. The shoots and grain of plants were oven-dried at $65^{\circ} \mathrm{C}$ and analyzed for elemental concentrations. The soil was air dried, ground, passed through a $1-\mathrm{mm}$ mesh sieve, and then thoroughly mixed.

\section{Zn and N Analysis}

According to the method of Bao (2002), Zn and N concentrations were determined using atomic absorption spectrometry (AAS) and Kjeldahl method, respectively. For the $\mathrm{Zn}$ analysis, five $\mathrm{mL}$ of the mixture $\mathrm{HNO}_{3}: \mathrm{HClO}_{4}(4: 1, \mathrm{v} / \mathrm{v})$ was used to digest the dry samples, and the $\mathrm{Zn}$ concentration of the digested samples was determined via flame AAS (ZEEnit 700, Analytik Jena AG, Germany). For the $\mathrm{N}$ analysis, five $\mathrm{mL}$ of $\mathrm{H}_{2} \mathrm{SO}_{4}$ and six drops of $\mathrm{H}_{2} \mathrm{O}_{2}$ were used to digest the dry samples, and the total $\mathrm{N}$ concentration of the digested samples was determined using a nitrogen autoanalyzer (BRAN LUEBBE AA3 Autoanalyzer, Germany). The certified standard reference materials (bush leaves, GBW07602 (GSV-1)), purchased from the National Center of Standard Material in China, was used to check the measurements.

\section{Soil Chemical Properties Analysis}

The physical and chemical properties of the soil including $\mathrm{pH}$, organic matter, alkaline hydrolysis $\mathrm{N}$, Olsen-P, available $\mathrm{K}$ and DTPA-extractable $\mathrm{Zn}$ were analyzed following the methods reported by Bao (2002).

\section{Chemical Fractions of $\mathrm{Zn}$ in Soil}

The method of sequential extraction used in this experiment was selected from the procedure of Tessier et al. (1979) and the revised method by Jiang et al. (1990). Six chemical fractions were separated as exchangeable, loose organic-bound, carbonatebound, Fe-Mn oxides-bound, tight organic-bound, and residual fractions. A summary of the procedure is as follows:
Two grams of soil was weighed into a $50-\mathrm{mL}$ polycarbonate centrifuge tube and added to the following solution to extract the different fractions. (1) Exchangeable: soil was extracted with $20 \mathrm{~mL}$ of $1 \mathrm{~mol} \mathrm{~L}^{-1} \mathrm{Mg}\left(\mathrm{NO}_{3}\right)_{2}$ (pH 7.0) for $2 \mathrm{~h}$ at $25^{\circ} \mathrm{C}$ with continuous shaking. (2) Loose organic: residue from the exchangeable fraction was extracted with $20 \mathrm{~mL}$ of $0.1 \mathrm{~mol} \mathrm{~L}^{-1}$ $\mathrm{Na}_{4} \mathrm{P}_{2} \mathrm{O}_{7}$ ( $\mathrm{pH} 9.5$ ) for $2 \mathrm{~h}$ at $25^{\circ} \mathrm{C}$ with continuous shaking. (3) Carbonate: residue from the loose organic fraction was extracted with $20 \mathrm{~mL}$ of $1 \mathrm{~mol} \mathrm{~L}^{-1} \mathrm{NaOAc}$ (adjusted to $\mathrm{pH}$ 5.0 with $\mathrm{HOAc}$ ) for $5 \mathrm{~h}$ at $25^{\circ} \mathrm{C}$ with continuous shaking. (4) Fe-Mn oxides: residue from the carbonate fraction was extracted with $20 \mathrm{~mL}$ of $0.1 \mathrm{~mol} \mathrm{~L} \mathrm{LH}_{2}^{-1} \mathrm{OH} \cdot \mathrm{HCl}(\mathrm{pH}$ 7.0) for $0.5 \mathrm{~h}$ at $25^{\circ} \mathrm{C}$ with continuous shaking. (5) Tight organic: residue from the $\mathrm{Fe}-\mathrm{Mn}$ oxides fraction was extracted with $20 \mathrm{~mL}$ of $30 \% \mathrm{H}_{2} \mathrm{O}_{2}(\mathrm{pH} 2.0)$ for $2 \mathrm{~h}$ at $85^{\circ} \mathrm{C}$ with continuous shaking. A second $20 \mathrm{~mL}$ of $30 \% \mathrm{H}_{2} \mathrm{O}_{2}(\mathrm{pH} 2.0)$ was added and heated again at $85^{\circ} \mathrm{C}$ for $3 \mathrm{~h}$ with intermittent shaking. After cooling, $20 \mathrm{~mL}$ of $1 \mathrm{~mol} \mathrm{~L}^{-1} \mathrm{Mg}\left(\mathrm{NO}_{3}\right)_{2}(\mathrm{pH}$ 7.0) was added, and the samples were shaken for $2 \mathrm{~h}$ at $25^{\circ} \mathrm{C}$. (6) Residual: two grams of soil was weighed into a 50$\mathrm{mL}$ Teflon crucible and digested using $\mathrm{HCl}-\mathrm{HNO}_{3}-\mathrm{HClO}_{4}-\mathrm{HF}$, which was used to analyze the total $\mathrm{Zn}$ concentration. The residual $\mathrm{Zn}$ was obtained via subtracting the sum of exchangeable, loose organic-bound, carbonate-bound, Fe-Mn oxides-bound, and tight organic-bound $\mathrm{Zn}$ concentrations from the total $\mathrm{Zn}$ concentration.

The $\mathrm{Zn}$ concentration of each extracted sample was determined via flame AAS (ZEEnit 700, Analytik Jena AG, Germany).

\section{Calculations and Statistical Analysis}

The chemical fractions of $\mathrm{Zn}$ were calculated as a percentage of the total $\mathrm{Zn}$ in all fractions.

The significance of the treatment effects and their interactions on the reported traits were evaluated by two-way or three-way ANOVA. The data are presented as averages of three replicates. Significant differences between means were determined using least significant difference (LSD) multiple comparisons $(P<0.05)$.

\section{RESULTS}

\section{Yield and Yield Components}

Two-way ANOVA revealed significant interactive effects of $\mathrm{N}$ and $\mathrm{Zn}$ application on the spike number per pot, the thousand kernel weight and the grain yield in winter wheat (Supplementary Table S1). There were significant effects of $\mathrm{N}$ application on the spike number per pot, the grain number per spike and the grain yield, as well as significant effects of $\mathrm{Zn}$ application on the spike number per pot, the thousand kernel weight and the grain yield in winter wheat.

Compared with $\mathrm{N}_{0.05}$ treatment, $\mathrm{N}_{0.2}$ treatment significantly increased the spike number per pot at each $\mathrm{Zn}$ treatment and the grain number per spike at $\mathrm{Zn} 0$ treatment; $\mathrm{N}_{0.4}$ treatment significantly increased the spike number per pot and the grain yield at each $\mathrm{Zn}$ treatment (Table 1 ). $\mathrm{Zn}_{10}$ treatment significantly 
TABLE 1 | Yield and yield components of winter wheat (Triticum aestivum cv Yunong 202), grown at 0.05, 0.2, and 0.4 $\mathrm{g} \mathrm{N} \mathrm{kg}^{-1}$ soil in a pot with 0, and $10 \mathrm{mg} Z \mathrm{n} \mathrm{kg}^{-1}$ soil supply for mature.

\begin{tabular}{|c|c|c|c|c|c|c|c|c|}
\hline \multirow[t]{2}{*}{ N supply } & \multicolumn{2}{|c|}{$\begin{array}{c}\text { Spike number } \\
\text { per pot }\end{array}$} & \multicolumn{2}{|c|}{$\begin{array}{c}\text { Grain number } \\
\text { per spike }\end{array}$} & \multicolumn{2}{|c|}{$\begin{array}{c}\text { Thousand kernel } \\
\text { weight }\end{array}$} & \multicolumn{2}{|c|}{$\begin{array}{l}\text { Grain yield } \\
\left(\mathrm{g} \mathrm{pot}^{-1}\right)\end{array}$} \\
\hline & $\mathrm{Zn}_{0}$ & $\mathrm{Zn}_{10}$ & $\mathrm{Zn}_{0}$ & $Z_{n_{10}}$ & $\mathrm{Zn}_{0}$ & $Z n_{10}$ & $\mathrm{Zn}_{0}$ & $\mathrm{Zn}_{10}$ \\
\hline $\mathrm{N}_{0.05}$ & $10.7 d$ & $13.0 d$ & $32.1 b$ & $35.5 a b$ & 48.5ab & 48.5ab & $17.6 \mathrm{c}$ & $21.1 \mathrm{bc}$ \\
\hline $\mathrm{N}_{0.2}$ & $18.3 \mathrm{c}$ & $20.3 c$ & 43.6a & $43.8 \mathrm{a}$ & $43.7 b$ & $46.6 \mathrm{~b}$ & $22.2 \mathrm{bc}$ & $25.0 b$ \\
\hline $\mathrm{N}_{0.4}$ & $24.0 \mathrm{~b}$ & $39.7 a$ & $34.9 \mathrm{ab}$ & $41.9 a$ & 48.5ab & $56.5 a$ & $24.4 b$ & $38.1 a$ \\
\hline
\end{tabular}

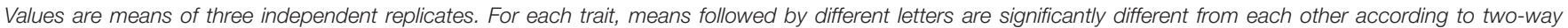
ANOVA followed by least significant difference $(L S D)$ multiple comparison $(P<0.05)$.

increased the spike number per pot and the grain yield only with $\mathrm{N}_{0.4}$ treatment. The spike number per pot, the thousand kernel weight and the grain yield were greater with $\mathrm{N}_{0.4} \mathrm{Zn}_{10}$ treatment than with any other treatment, but the highest value of grain number per spike was observed with the $\mathrm{N}_{0.2} \mathrm{Zn}_{10}$ treatment.

\section{$\mathrm{N}$ and $\mathrm{Zn}$ Concentration in Shoots and Grain}

Two-way ANOVA revealed significant interactive effects of $\mathrm{N}$ and $\mathrm{Zn}$ application on the $\mathrm{N}$ concentration in shoots and grain at the tillering, jointing and mature stages and on the $\mathrm{Zn}$ concentration in shoots and grain at each growth stage (Supplementary Table S1). $\mathrm{N}$ and $\mathrm{Zn}$ application had significant effects on $\mathrm{N}$ and $\mathrm{Zn}$ concentrations in shoots and grain at different growth stages, except for the $\mathrm{N}$ concentration in shoots at the mature stage.

$\mathrm{N}$ and $\mathrm{Zn}$ concentrations in shoots and grain were increased with the increase in $\mathrm{N}$ application at each growth stage, at each $\mathrm{Zn}$ application rate (Tables 2, 3). At the tillering stage, $\mathrm{Zn}$

TABLE 2 | $\mathrm{N}$ and $\mathrm{Zn}$ concentration in shoot of winter wheat (Triticum aestivum cv Yunong 202), grown at $0.05,0.2$, and $0.4 \mathrm{~g} \mathrm{~N} \mathrm{~kg}^{-1}$ soil in a pot with 0 , and $10 \mathrm{mg}$ $\mathrm{Zn} \mathrm{kg}^{-1}$ soil supply at different growth stage.

\begin{tabular}{|c|c|c|c|c|c|}
\hline \multirow[t]{2}{*}{ Growth Stage } & \multirow[t]{2}{*}{ N supply } & \multicolumn{2}{|c|}{$\begin{array}{c}N \text { concentration } \\
(\mathrm{g} / \mathrm{kg})\end{array}$} & \multicolumn{2}{|c|}{$\begin{array}{c}\text { Zn concentration } \\
(\mathrm{mg} / \mathrm{kg})\end{array}$} \\
\hline & & $\mathrm{Zn}_{0}$ & $Z_{10}$ & $\mathrm{Zn}_{0}$ & $Z_{10}$ \\
\hline \multirow[t]{3}{*}{ Tillering } & $\mathrm{N}_{0.05}$ & $5.41 f$ & $7.28 \mathrm{e}$ & $8.70 f$ & $11.7 \mathrm{e}$ \\
\hline & $\mathrm{N}_{0.2}$ & $9.33 d$ & $10.6 \mathrm{c}$ & $14.3 d$ & $19.6 c$ \\
\hline & $\mathrm{N}_{0.4}$ & $18.1 b$ & $19.6 a$ & $25.9 b$ & $39.0 a$ \\
\hline \multirow[t]{3}{*}{ Jointing } & $\mathrm{N}_{0.05}$ & $17.9 d$ & $15.9 \mathrm{~cd}$ & $28.1 \mathrm{e}$ & $31.1 \mathrm{e}$ \\
\hline & $\mathrm{N}_{0.2}$ & $22.2 \mathrm{c}$ & $31.9 b$ & $45.4 d$ & $74.9 \mathrm{~b}$ \\
\hline & $\mathrm{N}_{0.4}$ & $36.2 a b$ & $38.3 a$ & $59.8 \mathrm{c}$ & $91.6 \mathrm{a}$ \\
\hline \multirow[t]{3}{*}{ Grain filling } & $\mathrm{N}_{0.05}$ & $3.92 \mathrm{C}$ & $4.20 c$ & $10.7 d$ & $12.9 \mathrm{~cd}$ \\
\hline & $\mathrm{N}_{0.2}$ & $5.46 \mathrm{c}$ & $9.89 b$ & $14.8 \mathrm{bc}$ & $12.9 \mathrm{~cd}$ \\
\hline & $\mathrm{N}_{0.4}$ & $13.8 \mathrm{a}$ & $14.6 \mathrm{a}$ & $17.0 \mathrm{~b}$ & $25.9 a$ \\
\hline \multirow[t]{3}{*}{ Mature } & $\mathrm{N}_{0.05}$ & $5.04 d$ & $4.38 d$ & $5.63 e$ & $10.1 d$ \\
\hline & $\mathrm{N}_{0.2}$ & $6.91 \mathrm{c}$ & $7.65 \mathrm{bc}$ & $13.2 \mathrm{~cd}$ & $16.2 \mathrm{c}$ \\
\hline & $\mathrm{N}_{0.4}$ & $8.96 b$ & $11.8 \mathrm{a}$ & $23.2 \mathrm{~b}$ & $43.3 a$ \\
\hline
\end{tabular}

Values are means of three independent replicates. For each trait, means followed by different letters are significantly different from each other according to twoway ANOVA followed by least significant difference (LSD) multiple comparison $(P<0.05)$.
TABLE 3 | N and Zn concentration in grain of winter wheat (Triticum aestivum cv. Yunong 202), grown at $0.05,0.2$, and $0.4 \mathrm{~g} \mathrm{~N} \mathrm{~kg}^{-1}$ soil in a pot with 0 , and $10 \mathrm{mg}$ $\mathrm{Zn} \mathrm{kg}{ }^{-1}$ soil supply for mature.

\begin{tabular}{lccccc}
\hline N supply & \multicolumn{2}{c}{$\begin{array}{c}\text { N concentration } \\
\text { (g/kg) }\end{array}$} & & \multicolumn{2}{c}{$\begin{array}{c}\text { Zn concentration } \\
\text { (mg/kg) }\end{array}$} \\
\cline { 2 - 3 } \cline { 5 - 6 } & $\mathbf{Z n}_{\mathbf{0}}$ & $\mathbf{Z n}_{\mathbf{1 0}}$ & & $\mathbf{Z n}_{\mathbf{0}}$ & $\mathbf{Z n}_{\mathbf{1 0}}$ \\
\hline $\mathrm{N}_{0.05}$ & $19.0 \mathrm{~d}$ & $20.9 \mathrm{c}$ & & $36.8 \mathrm{c}$ & $43.7 \mathrm{c}$ \\
$\mathrm{N}_{0.2}$ & $23.5 \mathrm{~b}$ & $22.0 \mathrm{c}$ & & $36.8 \mathrm{c}$ & $56.4 \mathrm{~b}$ \\
$\mathrm{~N}_{0.4}$ & $24.6 \mathrm{~b}$ & $27.4 \mathrm{a}$ & & $66.0 \mathrm{~b}$ & $102 \mathrm{a}$ \\
\hline
\end{tabular}

Values are means of three independent replicates. For each trait, means followed by different letters are significantly different from each other according to twoway ANOVA followed by least significant difference (LSD) multiple comparison $(P<0.05)$

application significantly increased $\mathrm{N}$ and $\mathrm{Zn}$ concentrations in shoots at different $\mathrm{N}$ application rates; at the jointing stage, $\mathrm{Zn}$ application significantly increased shoot $\mathrm{N}$ concentration with $\mathrm{N}_{0.2}$ treatment and shoot $\mathrm{Zn}$ concentration with $\mathrm{N}_{0.2}$ and $\mathrm{N}_{0.4}$ treatments; at the grain filling stage, $\mathrm{Zn}$ application significantly increased shoot $\mathrm{N}$ concentration with $\mathrm{N}_{0.2}$ treatment and shoot $\mathrm{Zn}$ concentration with $\mathrm{N}_{0.4}$ treatment; at the mature stage, $\mathrm{Zn}$ application significantly increased $\mathrm{N}$ and $\mathrm{Zn}$ concentrations in shoots with $\mathrm{N}_{0.4}$ treatment and $\mathrm{Zn}$ concentration in shoots with $\mathrm{N}_{0.05}$ treatment, as well as grain $\mathrm{N}$ concentration at each $\mathrm{N}$ treatment and grain $\mathrm{Zn}$ concentration with $\mathrm{N}_{0.2}$ and $\mathrm{N}_{0.4}$ treatments. $\mathrm{N}$ and $\mathrm{Zn}$ concentrations in the shoots and grain of winter wheat were highest with $\mathrm{N}_{0.4} Z_{10}$ treatment compared with the other treatments.

\section{Available Zn Concentration in Soil}

As revealed by three-way ANOVA, the available $\mathrm{Zn}$ concentration in soil was significantly affected by the plant, the $\mathrm{N}$ and $\mathrm{Zn}$ applications, and the interaction of plant $\times \mathrm{N}$, plant $\times \mathrm{Zn}$, $\mathrm{N} \times \mathrm{Zn}$, and plant $\times \mathrm{N} \times \mathrm{Zn}$ at each growth stage, except for the plant $\times \mathrm{Zn}$ interaction at the grain filling stage (Supplementary Table S2).

With each treatment and at each growth stage, the available $\mathrm{Zn}$ concentration in soil without plants was higher than that in soil with plants (Figure 1).

For the soil without plants, $\mathrm{N}_{0.2}$ treatment significantly increased the available $\mathrm{Zn}$ concentration with $\mathrm{Zn}_{0}$ and $\mathrm{Zn}_{10}$ treatments at the tillering stage and only increased the 

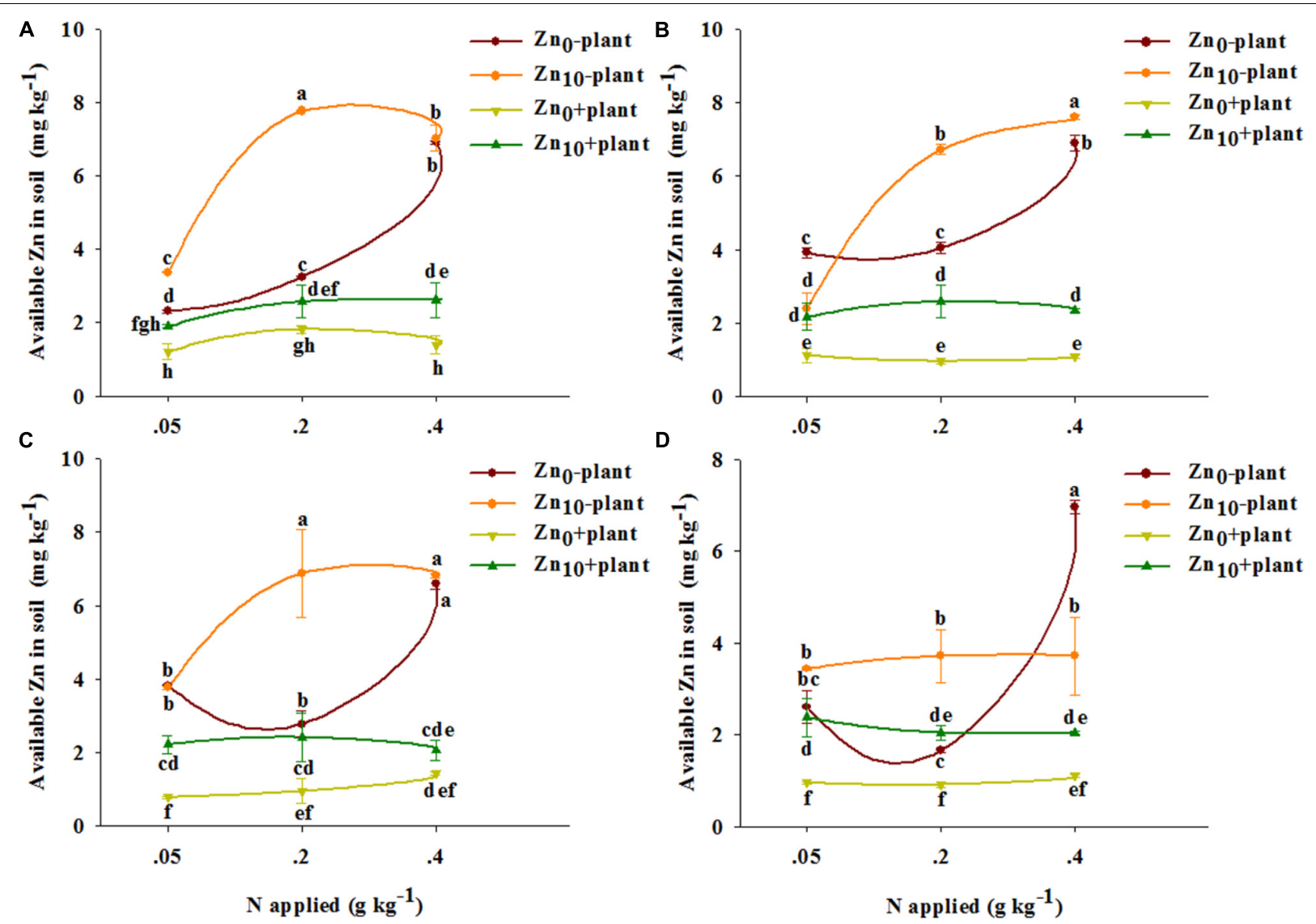

FIGURE 1 | Available Zn concentration in soil of winter wheat (Triticum aestivum cv Yunong 202) at the tillering (A), jointing (B), grain filling (C), and mature (D) stage with three $\mathrm{N}$ application rates $\left(0.05,0.2\right.$, and $0.4 \mathrm{~g} \mathrm{~N} \mathrm{~kg}^{-1}$ soil) and two Zn application rates (0 and $10 \mathrm{mg} \mathrm{Zn} \mathrm{kg}^{-1}$ soil), without and with plants. Values are means of three independent replicates. Error bars represent $1 \mathrm{SE}$. Means followed by different letters are significantly different from each other according to three-way ANOVA followed by least significant difference (LSD) multiple comparison $(P<0.05)$.

concentration with $\mathrm{Zn}_{10}$ treatment at the jointing and grain filling stages; $\mathrm{N}_{0.4}$ treatment significantly increased the available $\mathrm{Zn}$ concentration with each $\mathrm{Zn}$ treatment at different growth stages, except for treatment with $\mathrm{Zn}_{10}$ at the mature stage (Figure 1). The available $\mathrm{Zn}$ concentration was significantly increased by $\mathrm{Zn}$ application with the treatment of $\mathrm{N}_{0.05}$ and $\mathrm{N}_{0.2}$ at the tillering stage, with the treatment of $\mathrm{N}_{0.2}$ and $\mathrm{N}_{0.4}$ at the jointing stage, and with $\mathrm{N}_{0.2}$ treatment at the grain filling and mature stages; however, $\mathrm{Zn}$ application significantly decreased the available $\mathrm{Zn}$ concentration with $\mathrm{N}_{0.05}$ treatment at the jointing stage and with $\mathrm{N}_{0.4}$ treatment at the mature stage.

For the soil with plants, $\mathrm{N}_{0.2}$ and $\mathrm{N}_{0.4}$ treatment significantly increased the available $\mathrm{Zn}$ concentration with $\mathrm{Zn}_{10}$ treatment at the tillering stage, and $\mathrm{N}_{0.4}$ treatment significantly increased the available $\mathrm{Zn}$ concentration with $\mathrm{Zn}_{0}$ treatment at the grain filling stage (Figure 1). The available $\mathrm{Zn}$ concentration was significantly increased by $\mathrm{Zn}$ application for each $\mathrm{N}$ treatment at different growth stages, except for that with $\mathrm{N}_{0.05}$ treatment at the tillering stage and with $\mathrm{N}_{0.4}$ treatment at the grain filling and mature stages.

Available $\mathrm{Zn}$ concentrations in soil with and without plants were highest with $\mathrm{N}_{0.2} \mathrm{Zn}_{10}$ or $\mathrm{N}_{0.4} \mathrm{Zn}_{10}$ treatment compared with the other treatments at the tillering, jointing and grain filling stages.

\section{pH in Soil}

As revealed by three-way ANOVA, the $\mathrm{pH}$ in soil was significantly affected by plants, by $\mathrm{N}$ application, and by the plant $\times \mathrm{N}$ interaction at each growth stage (Supplementary Table S2). Zn application had significant effects on soil $\mathrm{pH}$ at the tillering, grain filling and mature stages. The interaction of plant $\times \mathrm{Zn}$ significantly affected soil $\mathrm{pH}$ at the grain filling and mature stages. The interaction of $\mathrm{N} \times \mathrm{Zn}$ significantly affected soil $\mathrm{pH}$ at the tillering, grain filling and mature stages. The interaction of plant $\times \mathrm{N} \times \mathrm{Zn}$ significantly affected soil $\mathrm{pH}$ at the tillering, jointing and grain filling stages.

For each treatment and each growth stage, $\mathrm{pH}$ in soil without plants was lower than that in soil with plants, except for that with $\mathrm{N}_{0.05} \mathrm{Zn}_{0}$ treatment at the tillering and grain filling stages (Figure 2).

For the soil without plants, $\mathrm{N}_{0.2}$ treatment significantly decreased $\mathrm{pH}$ with $\mathrm{Zn}_{0}$ treatment at the tillering, grain filling and mature stages, and decreased it with $\mathrm{Zn}_{0}$ and $\mathrm{Zn}_{10}$ treatment at the jointing stage; $\mathrm{N}_{0.4}$ treatment significantly 

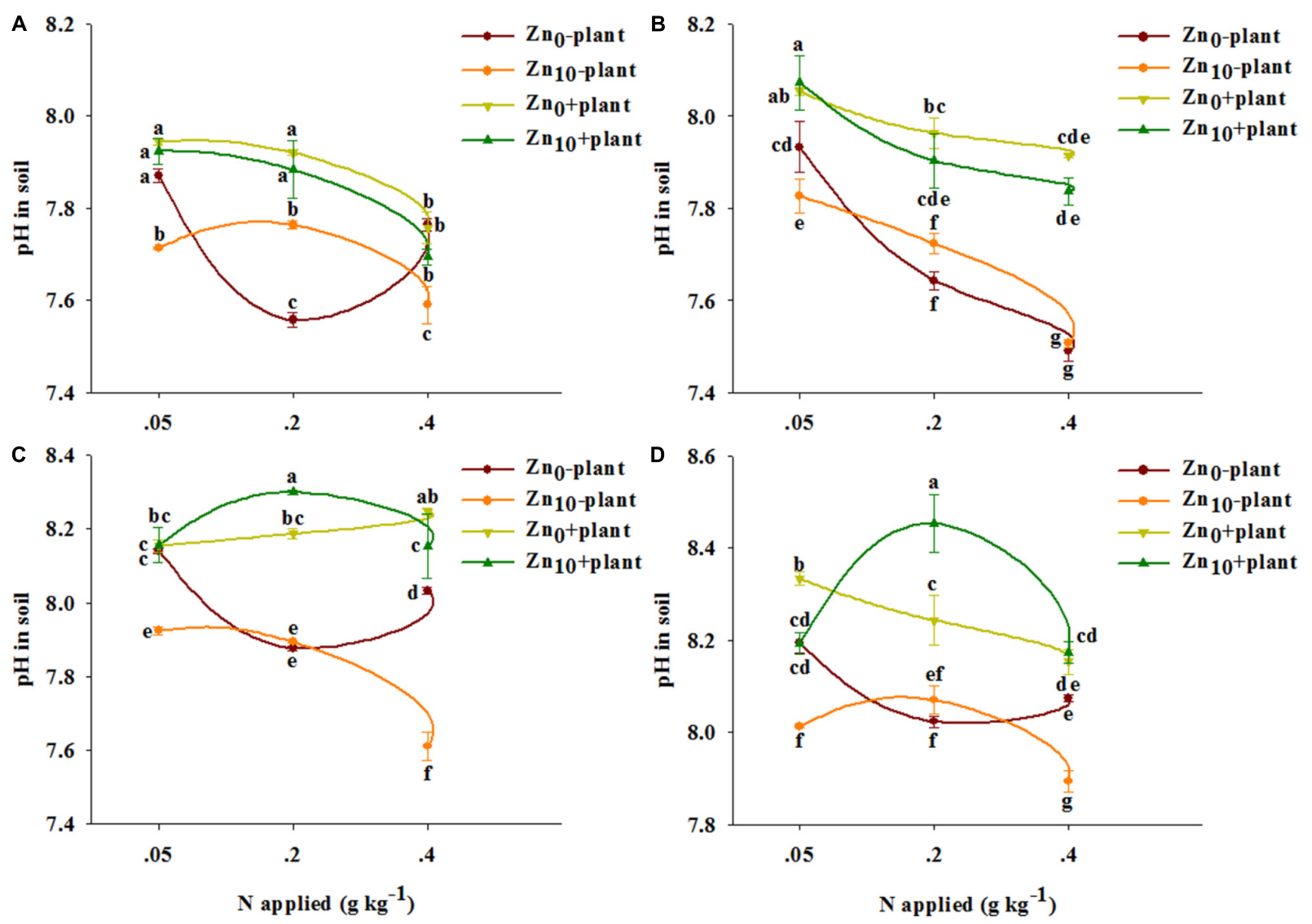

FIGURE 2 | pH in soil of winter wheat (Triticum aestivum cv. Yunong 202) at the tillering (A), jointing (B), grain filling (C), and mature (D) stage with three $\mathbf{N}$

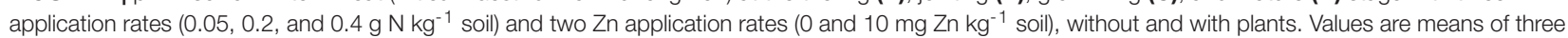
independent replicates. Error bars represent $1 \mathrm{SE}$. Means followed by different letters are significantly different from each other according to three-way ANOVA followed by least significant difference (LSD) multiple comparison $(P<0.05)$.

decreased $\mathrm{pH}$ with each $\mathrm{Zn}$ treatment at different growth stages (Figure 2). $\mathrm{pH}$ was significantly decreased by $\mathrm{Zn}$ application with $\mathrm{N}_{0.05}$ treatment at each growth stage; for $\mathrm{N}_{0.2}$ treatment, $\mathrm{pH}$ was significantly decreased by $\mathrm{Zn}$ application at the tillering stage; $\mathrm{Zn}$ application significantly decreased $\mathrm{pH}$ with $\mathrm{N}_{0.4}$ treatment at the tillering, grain filling and mature stages.

For the soil with plants, $\mathrm{N}_{0.2}$ treatment significantly decreased $\mathrm{pH}$ with $\mathrm{Zn}_{10}$ treatments at the jointing stage, as well as with $\mathrm{Zn}_{0}$ treatment at the mature stage, but increased $\mathrm{pH}$ with $\mathrm{Zn}_{10}$ treatment at the grain filling and mature stages; $\mathrm{N}_{0.4}$ treatment significantly decreased $\mathrm{pH}$ with $\mathrm{Zn}_{0}$ and $\mathrm{Zn}_{10}$ treatments at the tillering and jointing stages, as well as with $\mathrm{Zn}_{0}$ treatment at the mature stage, but increased $\mathrm{pH}$ with $\mathrm{Zn}_{0}$ treatment at the grain filling stage (Figure 2). $\mathrm{Zn}$ application significantly increased $\mathrm{pH}$ with $\mathrm{N}_{0.2}$ treatment but decreased it with $\mathrm{N}_{0.4}$ treatment at the grain filling stage; $\mathrm{Zn}$ application significantly decreased $\mathrm{pH}$ with $\mathrm{N}_{0.05}$ treatment but increased it with $\mathrm{N}_{0.4}$ treatment at the mature stage.

$\mathrm{pH}$ in soil with and without plants was highest with $\mathrm{N}_{0.4} \mathrm{Zn}_{10}$ treatment compared with the other treatments.

\section{Chemical Fractions of Zn Concentration in Soil}

Three-way ANOVA revealed significant interaction of plant $\times \mathrm{N} \times \mathrm{Zn}$ on the exchangeable and residual $\mathrm{Zn}$ concentration at the tillering stage, the loose organic-bound $\mathrm{Zn}$ concentration at each growth stage, the carbonate-bound $\mathrm{Zn}$ concentration at the tillering and mature stages, the Fe$\mathrm{Mn}$ oxides-bound $\mathrm{Zn}$ concentration at the jointing and grain filling stages, and the tight organic-bound $\mathrm{Zn}$ concentration at the jointing, grain filling and mature stages (Supplementary Table S3).

With the treatments of $\mathrm{N}_{0.2} \mathrm{Zn}_{10}$ and $\mathrm{N}_{0.4} \mathrm{Zn}_{10}$ at different growth stage, the exchangeable $\mathrm{Zn}$ in soil without plants was lower, but the carbonate-bound, Fe-Mn oxides-bound and residual $\mathrm{Zn}$ in soil without plants was higher than that in soil with plants (Table 4). There were opposite results for loose organicand tight organic-bound $\mathrm{Zn}$ with and without plants in different treatments at various growth stages.

$\mathrm{N}_{0.2}$ and $\mathrm{N}_{0.4}$ treatments significantly decreased the exchangeable $\mathrm{Zn}$ concentration in soil without plants, but increased that in soil with plants at each growth stage, regardless 
TABLE 4 | Zn fractions in soil of winter wheat (Triticum aestivum cv. Yunong 202), grown at 0.05, 0.2, and $0.4 \mathrm{~g} \mathrm{~N} \mathrm{~kg}^{-1}$ soil in a pot with 0 , and $10 \mathrm{mg} Z \mathrm{n} \mathrm{kg}^{-1}$ soil supply at different growth stage $\left(\mathrm{mg} \mathrm{kg}^{-1}\right)$.

\begin{tabular}{|c|c|c|c|c|c|c|c|c|c|c|}
\hline \multirow[t]{3}{*}{ Fractions } & \multirow[t]{3}{*}{ Plant } & \multirow[t]{3}{*}{ N supply } & \multicolumn{8}{|c|}{ Growth Stage } \\
\hline & & & \multicolumn{2}{|c|}{ Tillering } & \multicolumn{2}{|c|}{ Jointing } & \multicolumn{2}{|c|}{ Grain filling } & \multicolumn{2}{|c|}{ Mature } \\
\hline & & & $\mathrm{Zn}_{0}$ & $\mathrm{Zn}_{10}$ & $\mathrm{Zn}_{0}$ & $\mathrm{Zn}_{10}$ & $\mathrm{Zn}_{0}$ & $\mathrm{Zn}_{10}$ & $\mathrm{Zn}_{0}$ & $\mathrm{Zn}_{10}$ \\
\hline \multirow[t]{6}{*}{ Exchangeable } & No plant & $\mathrm{N}_{0.05}$ & $0.87 a$ & $0.68 b$ & $0.80 a$ & $0.64 b$ & $1.29 \mathrm{ab}$ & $1.36 \mathrm{a}$ & $0.58 a b$ & $0.40 \mathrm{bc}$ \\
\hline & & $\mathrm{N}_{0.2}$ & $0.41 e$ & 0.49de & $0.45 c$ & $0.38 c$ & $0.42 d$ & $0.43 d$ & $0.27 c$ & $0.31 c$ \\
\hline & & $\mathrm{N}_{0.4}$ & $0.58 c d$ & 0.50de & $0.23 d$ & $0.43 c$ & $0.46 d$ & $0.57 d$ & $0.46 \mathrm{bc}$ & $0.34 c$ \\
\hline & plant & $\mathrm{N}_{0.05}$ & $0.48 \mathrm{de}$ & $0.66 \mathrm{bc}$ & $0.40 c$ & $0.41 c$ & $1.13 c$ & $1.16 \mathrm{bc}$ & $0.29 c$ & $0.27 c$ \\
\hline & & $\mathrm{N}_{0.2}$ & $0.64 \mathrm{bc}$ & $0.81 a$ & $0.60 \mathrm{~b}$ & $0.59 b$ & $1.12 \mathrm{c}$ & $1.34 a$ & $0.65 a$ & $0.56 a b$ \\
\hline & & $\mathrm{N}_{0.4}$ & $0.66 \mathrm{bc}$ & $0.69 b$ & $0.47 \mathrm{c}$ & $0.58 b$ & $1.24 a b c$ & $1.41 \mathrm{a}$ & $0.42 \mathrm{bc}$ & $0.55 a b$ \\
\hline \multirow[t]{6}{*}{ Loose organic-bound } & No plant & $\mathrm{N}_{0.05}$ & 1.39gh & $1.29 \mathrm{~h}$ & 3.01cde & $3.54 \mathrm{bcd}$ & $4.03 c$ & 2.49ef & $1.40 \mathrm{~cd}$ & $0.77 \mathrm{de}$ \\
\hline & & $\mathrm{N}_{0.2}$ & $0.75 h$ & $0.91 \mathrm{~h}$ & $6.70 a$ & $3.09 \mathrm{cde}$ & 3.34 cde & $3.53 \mathrm{~cd}$ & 0.91de & $0.71 e$ \\
\hline & & $\mathrm{N}_{0.4}$ & $8.64 a$ & $5.55 b$ & $3.16 \mathrm{cde}$ & $2.05 \mathrm{fg}$ & $8.05 a$ & $5.95 b$ & $0.78 \mathrm{de}$ & $0.82 \mathrm{de}$ \\
\hline & plant & $\mathrm{N}_{0.05}$ & $2.54 \mathrm{ef}$ & $3.05 \mathrm{de}$ & $1.73 \mathrm{~g}$ & 2.32efg & $2.33 f$ & $3.63 \mathrm{~cd}$ & $1.96 c$ & $3.95 a$ \\
\hline & & $\mathrm{N}_{0.2}$ & $2.17 f$ & $3.53 \mathrm{~cd}$ & $2.74 \mathrm{def}$ & $3.79 b c$ & $2.00 f$ & $1.91 f$ & $2.73 b$ & $3.20 b$ \\
\hline & & $\mathrm{N}_{0.4}$ & $1.97 \mathrm{fg}$ & $3.89 c$ & $2.05 \mathrm{fg}$ & $4.23 b$ & $2.75 \mathrm{def}$ & $2.56 \mathrm{ef}$ & 0.90de & $1.12 \mathrm{de}$ \\
\hline \multirow[t]{7}{*}{ Carbonate-bound } & No plant & $\mathrm{N}_{0.05}$ & $2.31 \mathrm{ef}$ & 2.83de & $3.41 b c$ & $3.92 \mathrm{ab}$ & $1.81 \mathrm{abc}$ & $1.65 \mathrm{bcd}$ & $3.87 a b$ & $3.88 a b$ \\
\hline & & $\mathrm{N}_{0.2}$ & $2.41 \mathrm{ef}$ & $4.49 a$ & 2.67de & 3.99ab & $1.23 \mathrm{e}$ & $1.95 a b$ & $3.73 b$ & $4.11 a b$ \\
\hline & & $\mathrm{N}_{0.4}$ & $3.98 \mathrm{ab}$ & $3.91 \mathrm{ab}$ & $3.01 \mathrm{~cd}$ & $4.21 \mathrm{a}$ & $1.87 \mathrm{abc}$ & $1.87 \mathrm{abc}$ & $4.63 a$ & $3.38 b$ \\
\hline & plant & $\mathrm{N}_{0.05}$ & 2.33ef & $3.39 \mathrm{bcd}$ & $2.28 \mathrm{e}$ & $2.31 e$ & $1.18 \mathrm{e}$ & 1.49 cde & $1.51 \mathrm{de}$ & 1.69 cde \\
\hline & & $\mathrm{N}_{0.2}$ & $2.11 f$ & $3.47 \mathrm{bc}$ & 2.59de & $2.21 e$ & 1.30de & $1.66 \mathrm{bcd}$ & $1.22 \mathrm{e}$ & $2.35 c$ \\
\hline & & $\mathrm{N}_{0.4}$ & $2.19 f$ & $3.18 \mathrm{~cd}$ & $2.72 \mathrm{de}$ & $3.19 \mathrm{~cd}$ & $1.58 \mathrm{bcde}$ & $2.08 \mathrm{a}$ & $1.34 \mathrm{e}$ & $2.28 \mathrm{~cd}$ \\
\hline & & & $\mathrm{Zn}_{0}$ & $Z n_{10}$ & $\mathrm{Zn}_{0}$ & $Z n_{10}$ & $Z n_{0}$ & $Z n_{10}$ & $Z n_{0}$ & $\mathrm{Zn}_{10}$ \\
\hline \multirow[t]{7}{*}{ Fe-Mn oxides-bound } & No plant & $\mathrm{N}_{0.05}$ & $0.48 a b c$ & $0.56 a$ & $0.65 \mathrm{de}$ & $0.66 d$ & $0.51 c$ & $0.67 a b c$ & $0.48 \mathrm{e}$ & $0.51 \mathrm{de}$ \\
\hline & & $\mathrm{N}_{0.2}$ & $0.41 \mathrm{abcde}$ & $0.51 \mathrm{ab}$ & 0.64de & $0.69 \mathrm{~cd}$ & $0.61 b c$ & $0.68 \mathrm{ab}$ & 0.52 cde & $0.67 a b c$ \\
\hline & & $\mathrm{N}_{0.4}$ & $0.52 \mathrm{ab}$ & $0.45 a b c d$ & $0.75 c d$ & $0.80 c$ & $0.79 a$ & $0.17 e$ & $0.69 \mathrm{ab}$ & $0.75 a$ \\
\hline & plant & $\mathrm{N}_{0.05}$ & 0.33 cde & $0.28 \mathrm{e}$ & $1.06 b$ & $1.27 \mathrm{a}$ & $0.53 \mathrm{bc}$ & $0.64 a b c$ & $0.54 \mathrm{bcde}$ & 0.53 cde \\
\hline & & $\mathrm{N}_{0.2}$ & $0.32 \mathrm{de}$ & $0.45 a b c d$ & $1.05 b$ & 0.53ef & $0.57 \mathrm{bc}$ & $0.53 \mathrm{bc}$ & $0.65 \mathrm{abcd}$ & $0.64 a b c d$ \\
\hline & & $\mathrm{N}_{0.4}$ & 0.39bcde & 0.41 abcde & 0.52ef & $0.50 f$ & $0.27 \mathrm{de}$ & $0.35 d$ & $0.67 \mathrm{abc}$ & $0.47 e$ \\
\hline & No plant & $\mathrm{N}_{0.05}$ & $0.62 c$ & $0.77 \mathrm{abc}$ & $0.72 \mathrm{abc}$ & $0.46 e$ & $0.33 e$ & $0.83 a$ & $1.20 a b$ & $1.25 \mathrm{a}$ \\
\hline \multirow[t]{5}{*}{ Tight organic-bound } & & $\mathrm{N}_{0.2}$ & $0.78 \mathrm{ab}$ & $0.80 a$ & $0.81 a$ & $0.29 f$ & $0.71 \mathrm{c}$ & $0.72 \mathrm{c}$ & 1.10abcd & 0.93 cde \\
\hline & & $\mathrm{N}_{0.4}$ & $0.74 a b c$ & $0.69 a b c$ & $0.49 \mathrm{e}$ & $0.66 \mathrm{bcd}$ & $0.75 \mathrm{bc}$ & $0.79 \mathrm{ab}$ & 0.98cde & $1.13 a b c$ \\
\hline & plant & $\mathrm{N}_{0.05}$ & $0.63 \mathrm{bc}$ & $0.69 \mathrm{abc}$ & 0.70abcd & 0.59 cde & $0.13 f$ & $0.14 f$ & $1.28 \mathrm{a}$ & $0.70 f$ \\
\hline & & $\mathrm{N}_{0.2}$ & $0.63 \mathrm{bc}$ & $0.68 \mathrm{abc}$ & 0.56de & $0.46 e$ & $0.16 f$ & $0.17 f$ & $0.68 f$ & $1.03 \mathrm{bcde}$ \\
\hline & & $\mathrm{N}_{0.4}$ & $0.65 a b c$ & $0.77 \mathrm{abc}$ & 0.68abcd & $0.79 a b$ & $0.28 \mathrm{e}$ & $0.46 d$ & 0.85 ef & 0.93de \\
\hline \multirow[t]{6}{*}{ Residual } & No plant & $\mathrm{N}_{0.05}$ & 74.6ab & $78.9 a$ & $38.6 e$ & $52.5 \mathrm{bcd}$ & $78.4 \mathrm{bcd}$ & $83.2 b$ & $79.2 \mathrm{bc}$ & 83.5ab \\
\hline & & $\mathrm{N}_{0.2}$ & $44.6 d$ & $64.4 \mathrm{bc}$ & $51.9 \mathrm{bcd}$ & $54.5 a b c$ & $92.7 \mathrm{~b}$ & $89.8 b$ & $72.8 \mathrm{~cd}$ & $81.7 a b c$ \\
\hline & & $\mathrm{N}_{0.4}$ & $53.1 d$ & $51.1 d$ & $52.0 \mathrm{bcd}$ & 58.9ab & $87.9 b$ & $119 a$ & $89.6 a$ & $82.5 a b c$ \\
\hline & plant & $\mathrm{N}_{0.05}$ & $45.2 d$ & $43.9 d$ & $46.7 \mathrm{~cd}$ & 59.3ab & $56.5 \mathrm{ef}$ & $53.4 f$ & $48.3 \mathrm{~g}$ & $60.5 \mathrm{ef}$ \\
\hline & & $\mathrm{N}_{0.2}$ & $45.4 d$ & $51.7 d$ & 46.4de & $58.9 a b$ & $54.2 \mathrm{ef}$ & 64.4def & $58.7 f$ & 63.4def \\
\hline & & $\mathrm{N}_{0.4}$ & $49.3 d$ & $64.1 \mathrm{c}$ & $52.5 \mathrm{bcd}$ & $61.3 a$ & 68.1 cde & $80.1 b c$ & $56.3 \mathrm{fg}$ & $68.7 \mathrm{de}$ \\
\hline
\end{tabular}

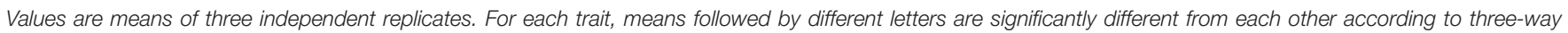
ANOVA followed by least significant difference (LSD) multiple comparison $(P<0.05)$.

of $\mathrm{Zn}$ application (Table 4). $\mathrm{N}_{0.2}$ or $\mathrm{N}_{0.4}$ treatment significantly increased the loose organic-bound $\mathrm{Zn}$ concentration in soil without plants, with $\mathrm{Zn}_{0}$ and $\mathrm{Zn}_{10}$ treatments at various growth stages; $\mathrm{N}_{0.2}$ and $\mathrm{N}_{0.4}$ treatment significantly increased the loose organic-bound $\mathrm{Zn}$ concentration in soil with plants at the tillering and jointing stage, but decreased that at the grain filling and mature stage with $\mathrm{Zn}_{10}$ treatment. The carbonate-bound $\mathrm{Zn}$ concentration in soil without and with plants was significantly increased by $\mathrm{N}_{0.2}$ or $\mathrm{N}_{0.4}$ treatment with $\mathrm{Zn}_{10}$ at each growth stage. $\mathrm{N}_{0.4}$ treatment significantly increased the Fe-Mn oxidesbound $\mathrm{Zn}$ concentration in soil without plant with $\mathrm{Zn}_{0}$ and $\mathrm{Zn}_{10}$ treatment at the tillering, jointing and mature stages, but decreased that in soil with plant with $\mathrm{Zn}_{0}$ and $\mathrm{Zn}_{10}$ treatment at various growth stages. There were different results for tight organic-bound $\mathrm{Zn}$ in soil with and without plants influenced by $\mathrm{N}$ application rates in different $\mathrm{Zn}$ application rates at various growth stages. $\mathrm{N}_{0.2}$ and $\mathrm{N}_{0.4}$ treatment significantly decreased the residual $\mathrm{Zn}$ concentration in soil without plants at the 
tillering stage, but increased that in soil without plants at the jointing, grain filling and mature stage and that in soil with plants at each growth stage, regardless of $\mathrm{Zn}$ application. $\mathrm{Zn}$ application had different influence on the each fraction of $\mathrm{Zn}$ in soil without and with plants with different $\mathrm{N}$ treatment at various growth stages.

$\mathrm{N}_{0.2} \mathrm{Zn}_{10}$ or $\mathrm{N}_{0.4} \mathrm{Zn}_{10}$ treatment had lower exchangeable and loose organic-bound $\mathrm{Zn}$ but higher carbonate- and Fe-Mn oxides-bound and residual $\mathrm{Zn}$ concentrations in soil without plants. The exchangeable, loose organic-, carbonate-bound, tight organic-bound and residual $\mathrm{Zn}$ concentrations in soil with plants were higher with $\mathrm{N}_{0.2} \mathrm{Zn}_{10}$ or $\mathrm{N}_{0.4} \mathrm{Zn}_{10}$ treatment compared with the other treatments.

\section{Proportions of $\mathrm{Zn}$ Chemical Fractions in Soil}

Three-way ANOVA revealed significant interaction of plant $\times \mathrm{N} \times \mathrm{Zn}$ on the exchangeable $\mathrm{Zn}$ proportion at the tillering and jointing stages, the loose organic-bound $\mathrm{Zn}$ proportion at each growth stage, the carbonate- and Fe-Mn oxides-bound $\mathrm{Zn}$ proportion at the jointing and grain filling stages, the tight organic-bound $\mathrm{Zn}$ proportion at the jointing, grain filling and mature stages, and the residual $\mathrm{Zn}$ proportion at the grain filling stages (Supplementary Table S4).

The differences for each fraction of $\mathrm{Zn}$ proportion between soil without and with plants was depended on the different treatment at various growth stages (Figure 3). With $\mathrm{Zn}_{0}, \mathrm{~N}_{0.2}$ and $\mathrm{N}_{0.4}$ treatments decreased the proportion of exchangeable and tight organic-bound $\mathrm{Zn}$ in soil without plants but increased the proportion of exchangeable and residual $\mathrm{Zn}$ in soil with plants at various growth stages; there were opposite results in the proportion of loose organic-, carbonate-, Fe-Mn oxides-, tight organic-bound and residual $\mathrm{Zn}$ in soil without and with plants influenced by $\mathrm{N}_{0.2}$ and $\mathrm{N}_{0.4}$ treatments at different growth stages. With $\mathrm{Zn}_{10}, \mathrm{~N}_{0.2}$ treatment decreased the proportion of exchangeable $\mathrm{Zn}$ in soil without plants but increased that in soil with plants; $\mathrm{N}_{0.4}$ treatment decreased the proportion of exchangeable $\mathrm{Zn}$ in soil without plants at various growth stages; different results were observed in the proportion of $\mathrm{Zn}$ fractions in soil without and with plants influenced by $\mathrm{N}_{0.2}$ and $\mathrm{N}_{0.4}$ treatments at different growth stages. $\mathrm{Zn}$ application also had different influence on the proportion of each $\mathrm{Zn}$ fraction in soil without and with plants with different $\mathrm{N}$ treatment at various growth stages.

\section{DISCUSSION}

\section{N Combined With Zn Application Increased Zn Concentration in Winter Wheat}

The grain yield, the yield components and the concentrations of $\mathrm{Zn}$ and $\mathrm{N}$ in the shoots of winter wheat were all significantly increased by $\mathrm{N}$ combined with $\mathrm{Zn}$ application, which produced the highest value (Tables 1, 2). These results suggested that $\mathrm{N}$ combined with $\mathrm{Zn}$ application was more beneficial to enhance the growth and that this combination increased $\mathrm{Zn}$ and $\mathrm{N}$ concentrations in shoots compared to $\mathrm{N}$ or $\mathrm{Zn}$ application alone. The enhancement of $\mathrm{Zn}$ concentration following the application of $\mathrm{N}$ combined with $\mathrm{Zn}$ has been suggested for the enhanced growth of plants (Aciksoz et al., 2011). Our results suggested that the increased $\mathrm{Zn}$ concentration in shoots might be partially related to the enhanced growth that occurred following the application of $\mathrm{N}$ combined with $\mathrm{Zn}$. On the other hand, $\mathrm{N}$ application had a positive effect on $\mathrm{Zn}$ absorption and root-to-shoot transport as $\mathrm{Zn}$ was supplied (Erenoglu et al., 2011). N combined with $\mathrm{Zn}$ application significantly increased $\mathrm{Zn}$ concentration in the shoot and grain of winter wheat (Tables 2, 3), suggesting $\mathrm{Zn}$ absorption and transfer from roots to shoots and translocation to grain, consistent with earlier studies with maize (Mehdi et al., 2012; Jamil et al., 2015). Zhao et al. (2016) showed that $\mathrm{N}$ combined with $\mathrm{Zn}$ application was beneficial for uptake, transfer and accumulation in winter wheat. Xue et al. (2012) and Nie et al. (2017) also observed that there was a significant positive correlation between $\mathrm{Zn}$ and $\mathrm{N}$ concentration and revealed that the enhanced $\mathrm{Zn}$ membrane transport and stimulated root development by $\mathrm{N}$ combined with $\mathrm{Zn}$ application in winter wheat was one reason for increasing $\mathrm{Zn}$ absorption and transfer to shoots. Thus, to increase $\mathrm{Zn}$ concentration in wheat grain cultured in $\mathrm{Zn}$-deficient soil, a combination of high $\mathrm{N}$ with $\mathrm{Zn}$ application is a better method.

\section{N Combined With Zn Application Increased Available Zn Concentration by Decreasing pH in Soil}

Calcareous soil is widely distributed in the Northern Winter Wheat Region of China. The soil used in our study was calcareous soil, and its available $\mathrm{Zn}$ (DTPA-Zn) concentration was $1.02 \mathrm{mg}$ $\mathrm{kg}^{-1}$, which was in the range of potential Zn deficiency in soil (Liu, 1994). The potentially $\mathrm{Zn}$ deficient soil was selected in our study based on the following three reasons. Firstly, the soils in most area of Henan Province are potentially Zn-deficient (Sun and Cai, 1984). Secondly, as the main grain producing area, Henan Province has a very high yield of grain crops, including winter wheat. The production of some high-yield or super-highyield crop varieties result in the increase in the demand for $\mathrm{Zn}$ nutrition of crops, thus $\mathrm{Zn}$ uptake in crops from the soil is also high. Thirdly, in our previous studies, this potentially $\mathrm{Zn}$ deficient soil was used as experimental material and found that the application of $\mathrm{Zn}$ fertilizer had a significant effect on increasing grain yield of winter wheat (Liu et al., 2015; Zhao et al., 2016; Nie et al., 2017). Calcareous soil is characterized by a high $\mathrm{CaCO}_{3}$ concentration, a high $\mathrm{pH}$ value and a low organic matter concentration, which can enhance the $\mathrm{Zn}$ fixation ability of soil and can reduce the bioavailability of $\mathrm{Zn}$, thus inhibiting Zn uptake in plant roots (Alloway, 2008). In our study, high $\mathrm{N}\left(\mathrm{N}_{0.4}\right)$ application induced significant increases in available $\mathrm{Zn}$ concentration in soil without plants in the absence of $\mathrm{Zn}$ application at each growth stage; medium $\mathrm{N}$ $\left(\mathrm{N}_{0.2}\right)$ application only increased it at 85 days (Figure 1). This 


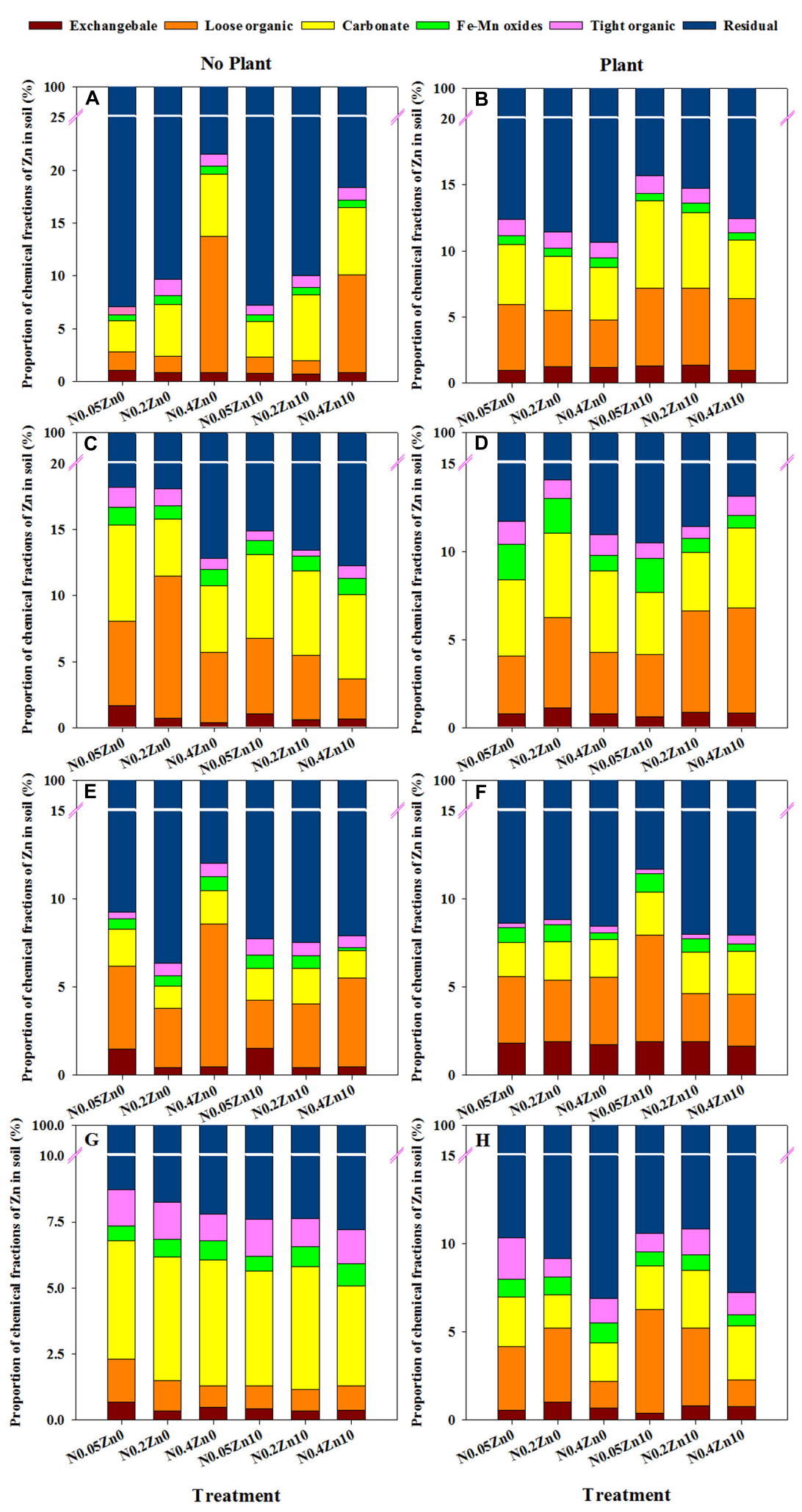

FIGURE 3 Proportion of chemical fractions of $\mathrm{Zn}$ in soil no-growing (A,C,E,G) and growing (B,D,F,H) winter wheat (Triticum aestivum cv Yunong 202) at the tillering $(\mathbf{A}, \mathbf{B})$, jointing $(\mathbf{C}, \mathbf{D})$, grain filling $(\mathbf{E}, \mathbf{F})$ and mature $(\mathbf{G}, \mathbf{H})$ stage with three $\mathrm{N}$ application rates $\left(0.05,0.2\right.$, and $0.4 \mathrm{~g} \mathrm{~N} \mathrm{~kg}^{-1}$ soil) and two $\mathrm{Zn}$ application rates $(0$ and $10 \mathrm{mg} \mathrm{Zn} \mathrm{kg}^{-1}$ soil), without and with plants. The proportion of chemical fractions of $\mathrm{Zn}(\%)$ was calculated as the percentage of $\mathrm{Zn}$ concentrations in each fraction to all fractions. Values are means of three independent replicates. 
suggested that the available $\mathrm{Zn}$ concentration was increased only when $\mathrm{N}$ was supplied at high levels under Zn-deficient conditions. With $\mathrm{Zn}$ application, $\mathrm{N}_{0.2}$ and $\mathrm{N}_{0.4}$ increased the $\mathrm{Zn}$ concentration in soil without plants at 85, 168, and 192 days (Figures 1A-C), indicating that $\mathrm{N}$ combined with $\mathrm{Zn}$ application could increase the availability of $\mathrm{Zn}$ in soil without plants. According to our conversion, $\mathrm{N}$ supplied at 225 and $450 \mathrm{~kg}$ $\mathrm{ha}^{-1}$ and $\mathrm{Zn}$ supplied at $11 \mathrm{~kg} \mathrm{ha}^{-1}$ might be beneficial for the increase of $\mathrm{Zn}$ availability in soil under the field condition. Our previous study showed that $\mathrm{N}\left(180\right.$ and $\left.270 \mathrm{~kg} \mathrm{ha}^{-1}\right)$ combined with $\mathrm{Zn}$ (15 and $30 \mathrm{~kg} \mathrm{Zn} \mathrm{ha}^{-1}$ ) treatment enhanced $\mathrm{Zn}$ absorption and accumulation in winter wheat grown in $\mathrm{Zn}$ deficient soil (Zhao et al., 2016), which might be the increased Zn availability in soil. Meanwhile, $\mathrm{N}$ combined with $\mathrm{Zn}$ application could increase the availability of $\mathrm{Zn}$ in soil with plants, which might be one reason for enhanced $\mathrm{Zn}$ absorption in winter wheat by application of $\mathrm{N}$ combined with $\mathrm{Zn}$. Our results are consistent with those of Lu et al. (2010), who noted that $\mathrm{N}$ combined with $\mathrm{Zn}$ application induced larger concentrations of available $\mathrm{Zn}$ in the $0-20 \mathrm{~cm}$ and $20-40 \mathrm{~cm}$ layers than with $\mathrm{N}$ and $\mathrm{Zn}$ application alone. Our results also showed that winter wheat roots significantly decreased the available $\mathrm{Zn}$ concentration in soil with plants compared with soil without plants at each growth stage (Figure 1). The major reason for this difference in available $\mathrm{Zn}$ concentration could be the $\mathrm{Zn}$ uptake by the roots of winter wheat (Mengel and Kirby, 1987).

The availability of $\mathrm{Zn}$ in soil increases with decreasing $\mathrm{pH}$ because the decreased $\mathrm{pH}$ weakens the affinity of soil to $\mathrm{Zn}$ by influencing $\mathrm{Zn}$ hydroxylation or the soil adsorption surface (Msaky and Calvet, 1990; Pardo and Guadalix, 1996). Our results showed that both $\mathrm{N}_{0.2}$ and $\mathrm{N}_{0.4}$ treatment decreased $\mathrm{pH}$ in $\mathrm{Zn}$ deficient soil without plants, and only $\mathrm{N}_{0.4}$ treatment decreased $\mathrm{pH}$ under $\mathrm{Zn}$ sufficiency at different growth days (Figure 2). Nitrate $\left(\mathrm{NO}_{3}{ }^{-}\right)$was used in our study as the $\mathrm{N}$ source, thus a possible reason for decreased $\mathrm{pH}$ in soil by $\mathrm{N}$ application was related to the leaching of $\mathrm{NO}_{3}{ }^{-}$inducing permanent soil acidity when the loss of $\mathrm{NO}_{3}{ }^{-}$uncouples a hydrogen ion $\left(\mathrm{H}^{+}\right)$-balancing system (Bolan et al., 1991). In addition, after transformation of $\mathrm{NO}_{3}^{-}$to ammonium ion $\left(\mathrm{NH}_{4}{ }^{+}\right)$in soil, $\mathrm{H}^{+}$is released through nitrification of $\mathrm{NH}_{4}{ }^{+}$(Zhou et al., 2014). For soils with plants, apart from the generation of $\mathrm{H}^{+}$in the soil $\mathrm{N}$ cycle (such as $\mathrm{NO}_{3}{ }^{-}$leaching and $\mathrm{NH}_{4}{ }^{+}$ nitrification), the change in $\mathrm{pH}$ is influenced by two kinds of root activities: root excretion, such as organic acid, can reduce the $\mathrm{pH}$ value, and plants absorb or secrete $\mathrm{H}^{+}$to maintain a neutral environment on the root-soil interface while absorbing the nutrient ions (Van Beusichem et al., 1988; Paterson et al., 2006). $\mathrm{H}^{+}$can enter the root cells through the $\mathrm{H}^{+} / \mathrm{NO}_{3}{ }^{-} \mathrm{co}-$ transfer system (Britto and Kronzucker, 2006), and the uptake of $\mathrm{NO}_{3}{ }^{-}$into plants has led to $\mathrm{H}^{+}$uptake and consequently to increasing $\mathrm{pH}$ in soil. We observed that the $\mathrm{pH}$ in soil with plants was higher than in soil without plants (Figure 2), suggesting that the increased $\mathrm{pH}$ by roots was caused by the synergetic absorption of $\mathrm{H}^{+} / \mathrm{NO}_{3}{ }^{-}$(Britto and Kronzucker, 2006). In our study, compared with $\mathrm{N}$ application alone, low $\mathrm{N}\left(\mathrm{N}_{0.05}\right)$ combined with $\mathrm{Zn}$ application decreased $\mathrm{pH}$ in soil with plants only at the mature stage (Figure 2D). This may have been because when $\mathrm{N}$ was supplied at low levels, the amount of $\mathrm{H}^{+}$generated in the soil $\mathrm{N}$ cycle was equal to the uptake by winter wheat, and the $\mathrm{H}^{+}$uptake declined with the decreasing uptake of $\mathrm{NO}_{3}{ }^{-}$when wheat was mature; thus, the $\mathrm{H}^{+}$generated in the $\mathrm{N}$ cycle of soil was dominant and decreased the $\mathrm{pH}$. However, medium $\mathrm{N}\left(\mathrm{N}_{0.2}\right)$ combined with $\mathrm{Zn}$ application decreased $\mathrm{pH}$ at the tillering and jointing stages but increased it at the grain filling and mature stages (Figure 2). This suggests that the soil $\mathrm{N}$ cycle and root excretion were dominant when wheat was at the vegetative period, thus decreasing $\mathrm{pH}$. In contrast, the synergetic absorption of $\mathrm{H}^{+} / \mathrm{NO}_{3}{ }^{-}$was dominant when wheat was at the reproductive stage, which was related to the highest $\mathrm{N}$ uptake of wheat at the jointing and grain filling stages, thus increasing the $\mathrm{pH}$ (Delogua et al., 1998). High $\mathrm{N}\left(\mathrm{N}_{0.4}\right)$ combined with $\mathrm{Zn}$ application decreased the $\mathrm{pH}$ at different growth stages (Figure 2), indicating that the change in $\mathrm{pH}$ was more influenced by the soil $\mathrm{N}$ cycle or root excretion than by the synergetic absorption of $\mathrm{H}^{+} / \mathrm{NO}_{3}{ }^{-}$. Therefore, exploring which of the above mentioned processes influenced by different $\mathrm{N}$ application rates in changing the $\mathrm{pH}$ in soil with plants is worth further study. In brief, our results indicated that the combined influence of roots and the combination of $\mathrm{N}$ and $\mathrm{Zn}$ enhanced $\mathrm{Zn}$ availability via decreasing $\mathrm{pH}$ in soils, which was agree with the results of Chen et al. (2010).

\section{N Combined With Zn Application Enhanced Zn Availability by Affecting the Transformation and Distribution of $\mathbf{Z n}$ in Various Soil Fractions}

Research has shown a close relationship between chemical fractions of $\mathrm{Zn}$ in soil and the availability of $\mathrm{Zn}$ in plants. Sungur et al. (2014) noted that plants can mainly take up $\mathrm{Zn}$ in the exchangeable and carbonate-bound fractions. $\mathrm{Li}$ et al. (2014) showed that exchangeable and organic matterbound $\mathrm{Zn}$ in contaminated soil declined significantly after phytoextraction, which further indicates that the exchangeable and organic matter-bound fractions were more available to the plants than the other fractions. The availability of $\mathrm{Zn}$ in soil increased with the enhanced transformation of $\mathrm{Zn}$ from tight organic matter-bound to light organic matterbound (Li et al., 2006). Guo et al. (2015) showed that the available $\mathrm{Zn}$ concentration was mainly influenced by exchangeable, light organic matter- and carbonate-bound fractions. In our experiment, $\mathrm{N}\left(\mathrm{N}_{0.2}\right.$ and $\left.\mathrm{N}_{0.4}\right)$ combined with $\mathrm{Zn}$ application decreased the exchangeable $\mathrm{Zn}$ but increased loose organic-, carbonate- and Fe-Mn oxidesbound $\mathrm{Zn}$ concentration in soil without plants at different growth days (Table 4), indicating that $\mathrm{N}$ combined with $\mathrm{Zn}$ application could influence the availability of $\mathrm{Zn}$ by changing the transformation between different fractions of $\mathrm{Zn}$ in soil. In addition, $\mathrm{pH}$ has been considered the most important factor affecting the transformation of $\mathrm{Zn}$ in various fractions (Wang et al., 2009). In soil with plants, $\mathrm{N}$ combined with $\mathrm{Zn}$ application increased the exchangeable, loose 
organic- and carbonate-bound $\mathrm{Zn}$ concentration in soil with plants at different growth stages (Table 4). This result also suggests that $\mathrm{N}$ combined with $\mathrm{Zn}$ application could increase the availability of $\mathrm{Zn}$ by enhancing the transformation of exchangeable, loose organic and carbonate-bound $\mathrm{Zn}$ from the other fractions. Possibly, root exudates provided exchangeable sites for $\mathrm{Zn}$ and increased cation exchange capacity in soil (Joergensen and Scheu, 1999; Khoshgoftarmanesh et al., 2018).

The highest proportion of $\mathrm{Zn}$ chemical fractions was the residual fraction (81.8-92.6\% of total $\mathrm{Zn}$ ), and a considerable amount of $\mathrm{Zn}$ was loose organic and carbonate-bound $\mathrm{Zn}$ at different growth stages (Figure 3), which agrees with the reports of Iyengar et al. (1981) and Lu et al. (2010). However, Xian (1987) reported that $30 \%$ of the total $\mathrm{Zn}$ was detected in the Fe-Mn oxides fraction. Xian (1989) showed that approximately $10 \%$ of the total $\mathrm{Zn}$ was associated with carbonates, and the proportion was raised according to the increase in inorganic C content in soil. Low, medium or high $\mathrm{N}$ combined with $\mathrm{Zn}$ application influenced the proportion of $\mathrm{Zn}$ in different fractions of soil with and without plants at different growth stages (Figure 3), also indicating that $\mathrm{N}$ combined with $\mathrm{Zn}$ application could influence the availability of $\mathrm{Zn}$ by changing the distribution of different $\mathrm{Zn}$ fractions in soil.

Winter wheat roots also significantly changed the concentration and proportion of $\mathrm{Zn}$ chemical fractions for soils with and without plants at each growth stage (Table 4 and Figure 3). However, the change in $\mathrm{Zn}$ chemical fractions by roots depended on the $\mathrm{N}$ and $\mathrm{Zn}$ application rates. Khoshgoftarmanesh et al. (2018) noted that roots induced higher exchangeable and organic matter-bound $\mathrm{Zn}$ through the input of acidity and organic compounds by roots and the associated microbial activity. Li et al. (2014) showed that root uptake resulted in the largest decrease in the exchangeable and organic matter-bound $\mathrm{Zn}$ in contaminated soil. Xu et al. (2006) reported that planting rice could increase the concentration of carbonate- and Fe-Mn oxidesbound $\mathrm{Zn}$ in soil. Thus, roots activities also influenced the availability of $\mathrm{Zn}$ via changing the transformation between chemical fractions of $\mathrm{Zn}$ in soil. But whether or how the roots

\section{REFERENCES}

Aciksoz, S., Yazici, A., Ozturk, L., and Cakmak, I. (2011). Biofortification of wheat with iron through soil and foliar application of nitrogen and iron fertilizers. Plant Soil 349, 215-225. doi: 10.1007/s11104-011-0863-2

Alloway, B. J. (2008). Zinc in Soils and Crop Nutrition. Paris: IZA and IFA.

Almendros, P., Gonzalez, D., and Alvarez, J. M. (2013). Long-term bioavailability effects of synthesized zinc chelates fertilizers on the yield and quality of a flax (Linum usitatissimum L.) crop. Plant Soil 368, 251-265. doi: 10.1007/s11104012-1502-2

Bao, S. (ed.). (2002). Soil Chemical Analysis. Beijing: China Agriculture Press.

Bolan, N. S., Hedley, M. J., and White, R. E. (1991). Processes of soil acidification during nitrogen cycling with emphasis on legume based pastures. Plant Soil 134, 53-63. doi: 10.1007/BF00010717

Bonaventuraa, P., Benedettia, G., Albarèdeb, F., and Miossec, P. (2015). Zinc and its role in immunity and inflammation. Autoimmun. Rev. 14, 277-285. doi: 10.1016/j.autrev.2014.11.008 activities are influenced by $\mathrm{N}$ combined with $\mathrm{Zn}$ application in influencing the $\mathrm{Zn}$ fractions in soil is also worth further study.

\section{CONCLUSION}

This study demonstrates that high $\mathrm{N}\left(0.4 \mathrm{~g} \mathrm{~kg}^{-1} \mathrm{~N}\right)$ combined with $10 \mathrm{mg} \mathrm{kg}^{-1} \mathrm{Zn}$ application is beneficial for enhancing crop yields, $\mathrm{Zn}$ uptake and transport to grain in winter wheat. Under the action of winter wheat roots, a combination of 0.2 or $0.4 \mathrm{~g}$ $\mathrm{kg}^{-1} \mathrm{~N}$ and $10 \mathrm{mg} \mathrm{kg}^{-1} \mathrm{Zn}$ can increase the $\mathrm{Zn}$ availability by decreasing the $\mathrm{pH}$ and enhancing the transformation and distribution of exchangeable, loose organic- and carbonatebound $\mathrm{Zn}$, thus promoting the $\mathrm{Zn}$ uptake in the roots of winter wheat.

\section{AUTHOR CONTRIBUTIONS}

$\mathrm{ZN}$ conceived and designed the experiments. PZ analyzed the data. SQ performed the experiments. HL wrote the paper.

\section{FUNDING}

This research was financially supported by the National Natural Science Foundation of China (Program No. 41501311, 41201286), the Key Scientific Research Project for the Universities of Henan Province (Program No. 17A210002), the Young Core Instructor Funding Scheme of Henan Province (Program No. 2013-045), and the National Key R\&D Program of China (Program No. 2017YFD0201700).

\section{SUPPLEMENTARY MATERIAL}

The Supplementary Material for this article can be found online at: https://www.frontiersin.org/articles/10.3389/fpls.2018.01489/ full\#supplementary-material

Bouis, H. E., Hotz, C., McClafferty, B., Meenakshi, J. V., and Pfeiffer, W. H. (2011). Biofortification: a new tool to reduce micronutrient malnutrition. Food Nutr. Bull. 32, S31-S40. doi: 10.1177/15648265110321S105

Britto, D. T., and Kronzucker, H. J. (2006). Futile cycling at the plasma membrane: a hallmark of low-affinity nutrient transport. Trends Plant Sci. 11, 529-534. doi: 10.1016/j.tplants.2006.09.011

Cakmak, I. (2008). Enrichment of cereal grains with zinc: agronomic or genetic biofortification? Plant Soil 302, 1-17. doi: 10.1007/s11104-007-9466-3

Cao, Y. X., Tian, X. H., Yang, X. W., Lu, X. C., and Nan, X. X. (2010). Variation of nutritional quality and their relationships in wheat and triticale grain. J. Northwest A F Univ. 38, 104-110.

Catlett, K. M., Heil, D. M., Lindsay, W. L., and Ebinger, M. H. (2002). Soil chemical properties controlling Zn2 + activity in 18 Colorado soils. Soil Sci. Soc. Am. J. 66, 1182-1189. doi: 10.2136/sssaj2002.1182

Chahal, D. S., Sharma, B. D., and Singh, P. K. (2005). Distribution of forms of zinc and their association with soil properties and uptake in different soil orders in semi-arid soils of Punjab. India. Commun. Soil Sci. Plan. 36, 2857-2874. doi: 10.1080/00103620500306031 
Chen, W., Chang, A. C., Wu, L., Page, A., and Koo, B. (2010). “Trace elements in biosolidsamended soils," in Trace Elements in Soils, 1st Edn, ed. P. S. Hooda (Hoboken, NJ: Blackwell Wiley), 313-336.

Clemens, S., Palmgren, M. G., and Kramer, U. (2002). A long way ahead: understanding and engineering plant metal accumulation. Trends Plant Sci. 7, 309-315. doi: 10.1016/S1360-1385(02)02295-1

Delogua, G., Cattivellia, L., Pecchionia, N., De Falcisb, D., Maggiorec, T., and Stancaa, A. M. (1998). Uptake and agronomic efficiency of nitrogen in winter barley and winter wheat. Eur. J. Agron. 9, 11-20. doi: 10.1016/S1161-0301(98) 00019-7

Erenoglu, E. B., Kutman, U. B., Ceylan, Y., Yildiz, B., and Cakmak, I. (2011). Improved nitrogen nutrition enhances root uptake, root-to-shoot translocation and remobilization of zinc (65Zn) in wheat. New Phytol. 189, 438-448. doi: 10.1111/j.1469-8137.2010.03488.x

Graham, R., Welch, R., and Bouis, H. (2001). Addressing micronutrient malnutrition through enhancing the nutritional quality of staple foods: principles, perspectives and knowledge gaps. Adv. Agron. 70, 77-142. doi: 10. 1016/S0065-2113(01)70004-1

Guo, C. H., Zhao, A. Q., Tian, X. H., Li, H. Y., and Li, S. (2015). Effects of Zn sources and application methods on the contents of various $\mathrm{Zn}$ fractions and Zn fertilizer utilization efficiency. J. Plant Nutr. Fert. 21, 1225-1233.

Hotz, C., and Brown, K. (2004). Assessment of the risk of zinc deficiency in populations and options for its control. Food Nutr. Bull. 25, 91-204.

Iyengar, S. S., Martens, D. C., and Miller, W. P. (1981). Distribution and plant availability of soil zinc fractions. Soil Sci. Soc. Am. J. 45, 735-739. doi: 10.2136/ sssaj1981.03615995004500040012x

Jamil, M., Sajad, A., Ahmad, M., Akhtar, F.-U.-Z., Abbasi, M. G. H., and Arshad, M. (2015). Growth, yield and quality of maize (Zea mays L.) fodder as affected by nitrogen-zinc interaction in arid climate. Pak. J. Agric. Sci. 52, 637-643.

Jiang, T., Hu, A., and Qin, H. (1990). Fractionation of soil zinc, copper, iron and manganese. Acta Sci. Circumstantiae 10, 280-286.

Joergensen, R. G., and Scheu, S. (1999). Response of soil microorganisms to the addition of carbon, nitrogen and phosphorus in a forest Rendzina. Soil Biol. Biochem. 31, 859-866. doi: 10.1016/S0038-0717(98)00185-0

Khoshgoftarmanesh, A. H., Afyunia, M., Norouzia, M., Ghiasia, S., and Schulin, R. (2018). Fractionation and bioavailability of zinc $(\mathrm{Zn})$ in the rhizosphere of two wheat cultivars with different $\mathrm{Zn}$ deficiency tolerance. Geoderma 309, 1-6. doi: 10.1016/j.geoderma.2017.08.019

Kutman, U. B., Yildiz, B., Ozturk, L., and Cakmak, I. (2010). Biofortification of durum wheat with zinc through soil and foliar applications of nitrogen. Cereal Chem. 87, 1-9. doi: 10.1094/CCHEM-87-1-0001

Li, J. X., Yang, X. E., He, Z. L., Jilani, G., Sun, C. Y., and Chen, S. M. (2007). Fractionation of lead in paddy soils and its bioavailability to rice plants. Geoderma 141, 174-180. doi: 10.1016/j.geoderma.2007.05.006

Li, M., Wang, S. X., Tian, X. H., Zhao, J. H., Li, H. Y., Guo, C. H., et al. (2015). $\mathrm{Zn}$ distribution and bioavailability in whole grain and grain fractions of winter wheat as affected by applications of soil $\mathrm{N}$ and foliar $\mathrm{Zn}$ combined with $\mathrm{N}$ or $\mathrm{P}$. J. Cereal Sci. 61, 26-32. doi: 10.1016/j.jcs.2014.09.009

Li, Y., Sun, L., and Sun, T. H. (2006). Transformation and phytoavailability of lead and znic forms in rhizospheric soil of common crops in north of China. Ecol. Environ. 15, 743-746.

Li, Z., Wu, L., Luo, Y., and Christie, P. (2014). Dynamics of plant metal uptake and metal changes in whole soil and soil particle fractions during repeated phytoextraction. Plant Soil 374, 857-869. doi: 10.1007/s11104-0131927-2

Lindsay, W. L. (1991). “"Inorganic equilibria affecting micronutrients in soils," in Micronutrients in Agriculture, eds J. J. Mortveldt, F. R. Cox, L. M. Shuman, and R. M. Welch (Madison, WI: Soil Science Society of America), 90-112.

Liu, H. E., Wang, Q. Y., Rengel, Z., and Zhao, P. (2015). Zinc fertilization alters flour protein composition of winter wheat genotypes varying in gluten content. Plant Soil Environ. 61, 195-200. doi: 10.17221/817/2014-PSE

Liu, Z. (1994). The distribution of zinc content in soil in China. Sci. Agric. Sin. 27, 30-37.

Lu, X. C., Tian, X. H., Yang, X. W., Mai, W. X., Bao, Q. L., and Zhao, A. Q. (2010). Effect of combined application of nitrogen and zinc on znic fraction and fertilizer efficiency in calcareous soil. Acta Pedol. Sin. 6, 1202-1213.
Mehdi, S. S., Husain, B., and Singh, L. (2012). Influence of seed rate, nitrogen and zinc on fodder maize (Zea mays) in temperate conditions of western Himalayas. Indian J. Agron. 57, 85-88.

Mench, M., and Fargue, S. (1994). Metal uptake by iron-efficient and inefficient oats. Plant Soil 165, 227-233. doi: 10.1007/BF00008066

Mengel, K., and Kirby, A. (1987). Principles of Plant Nutrition. Bern: International Potash Institute.

Msaky, J., and Calvet, R. (1990). Adsorption behavior of copper and zinc in soils: influence of $\mathrm{pH}$ on adsorption characteristics. Soil Sci. 150, 513-522. doi: 10.1097/00010694-199008000-00004

Nie, Z., Zhao, P., Wang, J., Li, J., and Liu, H. E. (2017). Absorption kinetics and subcellular fractionation of zinc in winter wheat in response to nitrogen supply. Front. Plant Sci. 8, 1435-1444. doi: 10.3389/fpls.2017.01435

Ortiz-Monasterio, J. I., Palacios-Rojas, N., Meng, E., Pixley, K., Trethowan, R., and Peña, R. J. (2007). Enhancing the mineral and vitamin content of wheat and maize through plant breeding. J. Cereal Sci. 46, 293-307. doi: 10.1016/j.jcs.2007. 06.005

Pardo, M., and Guadalix, M. (1996). Zinc sorption-desorption by two andepts: effect of pH and support medium. Eur. J. Soil Sci. 47, 257-263. doi: 10.1111/ j.1365-2389.1996.tb01397.x

Paterson, E., Sim, A., Standing, D., Dorward, M., and McDonald, A. J. S. (2006). Root exudation from Hordeum vulgare in response to localized nitrate supply. J. Exp. Bot. 57, 2413-2420. doi: 10.1093/jxb/erj214

Prasad, A. S. (2014). Impact of the discovery of human zinc deficiency on health. J. Trace Elem. Med. Biol. 28, 357-363. doi: 10.1016/j.jtemb.2014.09.002

Shuman, L., and Wang, J. (1997). Effect of rice variety on zinc, cadmium, iron, and manganese content in rhizosphere and non-rhizosphere soil fractions. Commun. Soil Sci. Plan. 28, 23-26. doi: 10.1080/00103629709369769

Sun, D. X., and Cai, D. L. (1984). Study on the content and geographical distribution of trace elements in henan soil. Central Plains Geogr. 1, 79-88.

Sungur, A., Soylak, M., and Ozcan, H. (2014). Investigation of heavy metal mobility and availability by the BCR sequential extraction procedure: relationship between soil properties and heavy metals availability. Chem. Spec. Bioavailab. 26, 219-230. doi: 10.3184/095422914X14147781158674

Tessier, A., Campbell, P. G. C., and Bisson, M. (1979). Sequential extraction procedure for the speciation of particulate trace metals. Anal. Chem. 51, 844-851. doi: 10.1021/ac50043a017

Udom, B. E., Mbagwu, J. S. C., Adesodun, J. K., and Agbim, N. N. (2004). Distribution of zinc, copper, cadmium and lead in a tropical ultisol after longterm disposal of sewage sludge. Environ. Int. 30, 467-470. doi: 10.1016/j.envint. 2003.09.004

Van Beusichem, M. L., Nelemans, J. A., and Bienfait, H. F. (1988). Interrelationships between trans-plasma membrane electron/proton transfer stoichiometry, organic acid metabolism, and nitrate reduction in dwarf bean (Phaseolus vulgaris). 87, 269-273. doi: 10.1104/pp.87.1.269

Velu, G., Ortiz-Monasterio, I., Cakmak, I., Hao, Y., and Singh, R. P. (2014). Biofortification strategies to increase grain zinc and iron concentrations in wheat. J. Cereal Sci. 59, 365-372. doi: 10.1016/j.jcs.2013.09.001

Wang, J., Zhang, C. B., and Jin, Z. X. (2009). The distribution and phytoavailability of heavy metal fractions in rhizosphere soils of Paulownia fortunei (seem) hems near a Pb/Zn smelter in Guangdong. PR China. Geoderma 148, 299-306. doi: 10.1016/j.geoderma.2008.10.015

Xian, X. (1987). Chemical partitioning of cadmium, zinc, lead, and copper in soils near smelter. J. Environ. Sci. Health 22, 527-541. doi: 10.1080/ 10934528709375368

Xian, X. (1989). Effect of chemical forms of cadmium, zinc, and lead in polluted soils on their uptake by cabbage plants. Plant Soil 113, 257-264. doi: 10.1007/ BF02280189

Xu, W. H., Wang, H. X., Liu, H., Xiong, Z. T., and Singh, B. (2007). Sigle and combined pollution of Zinc and Cadmium influence on root exudates and $\mathrm{Zn}$, Cd forms in rygrass. Acta Sci. Circumstantiae 28, 2089-2095.

Xu, W. H., Wang, Z. Y., Yuan, D. H., Cao, Q. H., and Guo, X. F. (2006). Effects of various an ionic zinc fertilizers on the rice nutrition andzinc forms in soil. Chin. J. Eco Agric. 14, 52-55.

Xue, Y. F., Yue, S. C., Zhang, Y. Q., Cui, Z. L., Chen, X. P., Yang, F. C., et al. (2012). Grain and shoot zinc accumulation in winter wheat affected by nitrogen management. Plant Soil 361, 153-163. doi: 10.1007/s11104-012-1510-2 
Zhang, Y., Wang, D. S., Zhang, Y., and He, Z. H. (2007). Variation of major mineral elements concentration and their relationships in grain of Chinese wheat. Sci. Agric. Sin. 40, 1871-1876.

Zhao, P., Yang, F., Sui, F., Wang, Q., and Liu, H. (2016). Effect of Nitrogen Fertilizers on Zinc Absorption and Translocation in Winter Wheat. J. Plant Nutr. 39, 1311-1318. doi: 10.1080/01904167.2015.1106560

Zhou, J., Xia, F., Liu, X. M., He, Y., Xu, J. M., and Brookes, P. C. (2014). Effects of nitrogen fertilizer on the acidification of two typical acid soils in South China. J. Soil Sediment 14, 415-422. doi: 10.1007/s11368-0130695-1
Conflict of Interest Statement: The authors declare that the research was conducted in the absence of any commercial or financial relationships that could be construed as a potential conflict of interest.

Copyright (c) $2018 \mathrm{Liu}$, Zhao, Qin and Nie. This is an open-access article distributed under the terms of the Creative Commons Attribution License (CC BY). The use, distribution or reproduction in other forums is permitted, provided the original author(s) and the copyright owner(s) are credited and that the original publication in this journal is cited, in accordance with accepted academic practice. No use, distribution or reproduction is permitted which does not comply with these terms. 